\title{
Community Mental Health Services in Ireland:
}

\section{Activity and Catchment Area \\ Characteristics 2004}

Mental Health Commission May 2006 
Activity and catchment area characteristics 2004

\section{Acknowledgements}

Introduction

Part I: Community mental health activity 2004 .10

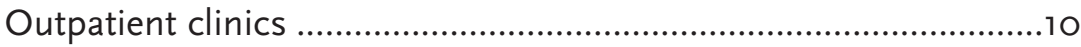

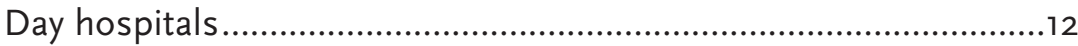

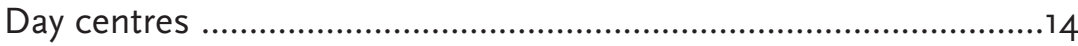

Community residences ………………………............................15

Information on other mental health services ………………...........17

Later life mental health services ......................................................17

Child and adolescent mental health services (CAMHS) ....................17

Mental health services for people with intellectual disability ...........17

Other mental health services ........................................................18

Future developments ................................................................18

Part II: Mental health catchment area profiles (deprivation maps and tables) ......20

Deprivation ...................................................................................20

Interpretation of tables and maps...............................................20

National Profile ......................................................................21

East Coast Area (deprivation maps and tables) ...........................22

Cluain Mhuire Mental Health Catchment Area 1 ...........................22

Mental Health Catchment Area 2 …............................................23

Mental Health Catchment Area 10 .................................................24

South Western Area (deprivation maps and tables) ..........................25

Mental Health Catchment Area 3....................................................25

Mental Health Catchment Area 4 \& 5 .............................................26

Mental Health Catchment Area 9 ..................................................27 
Northern Area (deprivation maps and tables) ……….....................28

Mental Health Catchment Area 6 ..................................................28

Mental Health Catchment Area 7 ......................................................29

Mental Health Catchment Area 8 .................................................. 30

Mid Western Area (deprivation maps and tables) ...........................31

Clare Mental Health Catchment Area ...............................................31

Limerick Mental Health Catchment Area .........................................32

Tipperary North Mental Health Catchment Area ............................33

Midlands Area (deprivation maps and tables) ..................................34

Laois/Offaly Mental Health Catchment Area ...................................34

Longford/Westmeath Mental Health Catchment Area ......................35

North Eastern Area (deprivation maps and tables) ..........................36

Cavan/Monaghan Mental Health Catchment Area............................36

Longford/Westmeath Mental Health Catchment Area .....................37

North Western Area (deprivation maps and tables)........................38

Donegal Mental Health Catchment Area..........................................38

Sligo/Leitrim Mental Health Catchment Area...................................39

South Eastern Area (deprivation maps and tables) ........................40

Tipperary South Mental Health Catchment Area ..............................40

Waterford Mental Health Catchment Area .........................................41

Wexford Mental Health Catchment Area...........................................42

Carlow/Kilkenny Mental Health Catchment Area .............................43

Southern Area (deprivation maps and tables) .................................44

Kerry Mental Health Catchment Area ...............................................44

North Cork Mental Health Catchment Area ......................................45

North Lee Mental Health Catchment Area ........................................46

South Lee Mental Health Catchment Area .......................................47

West Cork Mental Health Catchment Area .......................................48 
Activity and catchment area characteristics 2004

Western Area (deprivation maps and tables) ...................................49

East Galway Mental Health Catchment Area ...................................49

West Galway Mental Health Catchment Area …….........................50

Mayo Mental Health Catchment Area ................................................51

Roscommon Mental Health Catchment Area ..................................52

References

Appendix 1: Mental Health Commission collection of statistical information for inpatient and community mental health activity 2004 (relevant sections of the form) .. $\mathrm{i}$

Appendix 2: Community residences - admissions and discharges .xvii

\section{Acknowledgements}

The Mental Health Commission wishes to thank all those involved in collecting information on mental health services in Ireland and those who supplied the data for this report. 


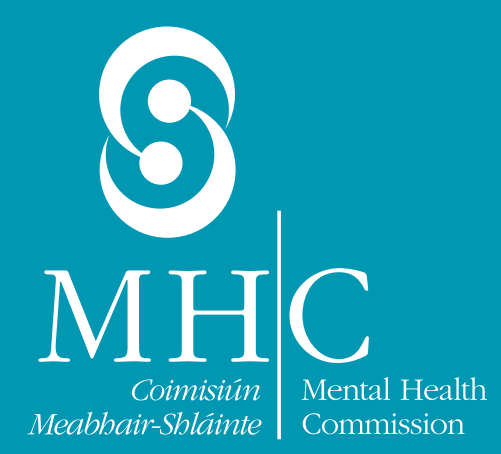

Introduction 
Activity and catchment area characteristics 2004

\section{INTRODUCTION}

This is the first report from the Mental Health Commission on the activity of community mental health services in Ireland. Information on the profile of deprivation in mental health catchment areas both in tabular and map form is also included in this report. The provision of this information builds on the detailed profile of catchment areas provided in the Annual Report of the Mental Health Commission for 2004 (published in 2005).

Information is one of the key tools of the Mental Health Commission. In order to progress the quality mandate under the Mental Health Act, 2001, and to carry out the various functions of the Commission under the Act, particularly in relation to the inspection of approved centres and other mental health services, comprehensive, timely and accurate mental health information is required on many different aspects of Irish mental health services. This mental health information is used to ensure that high quality mental health services are accessible in an equitable fashion, to all those who require them, right across the country. The Mental Health Commission places a high value on data and on the information derived from that data.

\section{Data on community mental health services}

Most of the activity in Irish mental health services goes on in community-based mental health services. Over the years a good deal of information has been available on inpatient mental health services from the annual reporting on the activities of psychiatric hospitals and units carried out by the Health Research Board. However, only more recently has there been published data on community mental health services. Collecting this community data presents challenges for the mental health services as there are many locations involved (as opposed to just one inpatient location in a catchment area) and there is a much greater variety of activity which is much harder to define.

\section{Data collection}

The process of data collection itself has been cumbersome and places a considerable burden on mental health services, largely because systems in many community mental health services are still manual and often paper-based. Collecting individualised data (such as the diagnosis of all outpatient attenders) is impossible with such systems. This situation has led to the production of data that is of variable quality, and which can be difficult to interpret due to the different understanding and definitions of different elements of the service, and which cannot provide all the data required by the Commission. The form for the collection of information on community mental health services in 2004 was sent 
out to services in February 2005. Because of the difficulty some services experience in collecting this information, there was a delay receiving data from some services. This has resulted in the late publication of 2004 data. Information on the end-of-year inpatient census was returned separately and has already been reported in the Annual Report of the Mental Health Commission 2004.

The Mental Health Commission is aware of the challenges involved in data collection and has engaged with those collecting the data in the mental health services in an effort to decrease the burden on the services, to facilitate the overall process of data collection and to improve the quality of data. Two meetings were held in 2005 with data collectors as part of this process and progress is being made. In addition, a scoping exercise on mental health information systems is currently being undertaken by the Commission. The purpose of this is to present the Commission with a detailed analysis of the current situation regarding mental health information systems in Ireland. The scoping exercise will also take cognisance of information systems in use in other jurisdictions with a view to recommending the optimum approach to establishing a national mental health information system in Ireland.

The information presented here is just one small part of the overall information that is required by the Mental Health Commission to fulfil its mandate. We have begun the process by collecting the information that has been collected in the past and is reasonably accurate and reliable. Much greater detail is required on the structures of Irish mental health services, the processes and activity of those mental health services and the outcomes for service users and their carers.

This is the beginning of a long journey in terms of defining and developing the data sets and systems that are required to ensure the wide availability of reliable data. There are many stakeholders in this process. The Mental Health Commission is well placed to facilitate this process so that the mental health information required by us and many others will be readily available. The ultimate aim of this process is to ensure that high quality mental health services are available to all service users and their carers. 
Activity and catchment area characteristics 2004 


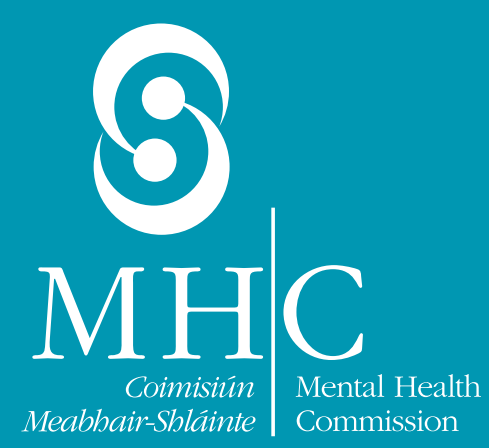

Part 1 
Activity and catchment area characteristics 2004

\section{Part I: Community mental health services activity 2004}

The data presented in this part of the report were collected by the data collectors in all the mental health services in Ireland for the full year 2004. All aspects of community mental health services were covered in the data collection form (see appendix 1), but not all are reported on here for a variety of reasons. In some instances, only a small number of catchment areas provide certain services such as mental health services for the homeless. Information which was deemed to be most accurate and reliable is reported in the following sections.

This is the second in a series of reports that will provide information on the provision and activity of mental health services in Ireland (The first Analysis of Information Mental Health Services (AIMS) report was part of the Annual Report of the Mental Health Commission 2004). It is also our intention to include further information on mental health catchment areas in each report to assist in the analysis of mental health services and their planning and evaluation.

Note: Throughout this report we refer to the former health boards as HSE Areas although these areas were still health boards in 2004.

\section{Outpatient clinics}

One facet of community mental health services which has the highest volume of activity is outpatient clinics. Outpatient clinic activity usually involves consultation with doctors and visits with nurses, and can include dispensing depot medication. In some clinics social workers, psychologists and occupational therapists also have appointments with service users. Data on the type of mental health professional involved in these clinics has not been collected to date. The Commission is aware that outpatient activity is also carried on in a variety of other locations, involving a range of mental health professionals. This activity remains 'invisible' because information on this type of activity is not collected in all mental health services and therefore not reported centrally. There is also little readily available information on the characteristics of those using outpatient clinics, such as the diagnostic profile of attenders. Unfortunately the systems are not currently in place to collect this information, although this information will be required in the future.

Table 1 shows the number of outpatient clinics held in 2004, the number of new patients attending these clinics and the total number of patients who attended, along with the total number of attendances. From the data we received, over 
14,000 outpatient clinics were held in 241 locations throughout Ireland in 2004. Over 81,000 patients attended these clinics of which 13,117 were new patients. An examination of the rates per 100,000 population over 16 years shows that there is considerable variation in these rates over all the Health Service Executive areas. However, some areas did not give complete returns for outpatient clinics, therefore these figures and variations must be interpreted with caution. The total number of attendances shows a drop on that of 2003, which was 238,650 (a rate of $7,879.1$ ) (Daly et al., 2004)'. Again this must be interpreted with caution, although it is in keeping with the trend of figures for 2003 also showing a decrease on the figures for 2002 (Daly et al., 2004).

Table 1: Outpatient clinics by HSE Area. Ireland 2004.

Numbers with rates per 100,000 population aged 16 years and over.*

\begin{tabular}{|c|c|c|c|c|c|c|c|c|}
\hline \multirow[t]{2}{*}{ HSE Area } & \multicolumn{2}{|c|}{$\begin{array}{l}\text { Number of } \\
\text { Clinics Held }\end{array}$} & \multicolumn{2}{|c|}{$\begin{array}{l}\text { Number of } \\
\text { New Patients } \\
\text { Attending }\end{array}$} & \multicolumn{2}{|c|}{$\begin{array}{l}\text { Total Number } \\
\text { of Patients }\end{array}$} & \multicolumn{2}{|c|}{$\begin{array}{l}\text { Total Number of } \\
\text { Attendances }\end{array}$} \\
\hline & Numbers & Rates & Numbers & Rates & Numbers & Rates & Numbers & Rates \\
\hline East Coast Area & 235 & 89.1 & 1,614 & 612.3 & 2,691 & $1,020.8$ & 24,138 & $9,156.7$ \\
\hline Northern Area & 2,298 & 598.1 & 745 & 193.9 & 3,867 & $1,006.4$ & 21,114 & $5,495.1$ \\
\hline South Western Area & $\mathrm{I}, 40 \mathrm{I}$ & 308.6 & $\mathrm{I}, 508$ & 332.1 & 32,283 & $7,110.0$ & 45,129 & $9,939.2$ \\
\hline Midlands Area & 764 & 446.4 & 812 & 474.4 & 1,790 & $1,045.9$ & 12,370 & $7,227.7$ \\
\hline Mid Western Area & 2,785 & $1,062.0$ & 1,390 & 530.0 & 4,881 & $1,861.2$ & 20,361 & $7,764.0$ \\
\hline North Eastern Area & I,778 & 691.0 & 1,445 & 561.6 & 16,199 & $6,296.0$ & 21,692 & $8,431.0$ \\
\hline North Western Area & 717 & 424.6 & 969 & 573.8 & 1,016 & 601.7 & 9,746 & $5,77 \mid .4$ \\
\hline South Eastern Area & 1,005 & 311.4 & 695 & 215.4 & 5,569 & I,725.7 & 10,577 & $3,277.6$ \\
\hline Southern Area & 2,147 & 476.2 & 2,970 & 658.8 & 8,023 & I,779.5 & 30,752 & $6,820.9$ \\
\hline Western Area & $1,3 \mid 8$ & 448.5 & 969 & 329.7 & 5,392 & I,834.7 & 16,765 & $5,704.5$ \\
\hline Total & 14,448 & 477.0 & 13,117 & 433.1 & $81,7 \mathrm{I}$ & $2,697.7$ & 212,644 & $7,020.5$ \\
\hline
\end{tabular}

*There were incomplete returns from some areas.

1 All references to 2003 figures are from Activities of Irish Psychiatric Services 2003, Daly, A., Moran, R., Walsh, D. \& Kartalova O'Doherty, Y. (2004) Health Research Board 
Activity and catchment area characteristics 2004

\section{Day hospitals}

In Planning for the Future $(1984)^{2}$ the function of the day hospital was described as providing "intensive treatment equivalent to that available in a hospital inpatient setting for acutely ill patients". The findings of a study by Hickey et al. $(2003)^{3}$ suggested that many day hospitals were not operating in this way and the data reported below supports that finding. Anecdotal evidence suggests that day hospitals are used to provide a wide variety of group work and other sessional activity which is not captured by simple measures of attendances. As with outpatient clinics, there is no information captured on the various mental health professionals involved in this activity, or the characteristics of day hospital attenders. This type of information will be required in the future.

There were 58 day hospitals in Ireland, providing a total of 1,022 places in 2004, a rate of 33.7 places per 100,000 population aged 16 and over (Table 2). The HSE Mid Western area had the highest rate of provision, with a rate of 75.9 places, while the HSE North Eastern area had the lowest provision, with a rate of 9.7 places. The number of persons attending day hospitals in 2004 was 19,110 (a rate of 630.9), resulting in a total of 162,233 attendances. There is less variability among HSE areas in day hospital activity as measured by number of attendances. However, there is evidence that some areas are measuring attendances in a different way. The issue of definitions of activity is currently being worked on by the Commission.

The number of places show a slight decrease on those for 2003 (1,090 places), with an increase on persons attending (19,110 compared to 16,637 in 2003) and a decrease on total attendances $(162,233$ compared to 171,196 in 2003).

2 Planning for the Future (1984), Department of Health, Dublin

3 Psychiatric Day Care - An Underused Option? Hickey, T. Moran, R. and Walsh D. (2003) Health Research Board, Dublin 
Table 2: Day Hospitals by HSE Area. Ireland 2004.

Numbers with rates per 100,000 population 16 years and over.*

\begin{tabular}{|c|c|c|c|c|c|c|}
\hline \multirow[b]{2}{*}{ HSE Area } & \multicolumn{2}{|l|}{ Places } & \multicolumn{2}{|c|}{ Persons Attending } & \multicolumn{2}{|c|}{ Attendances } \\
\hline & Numbers & Rates & Numbers & Rates & Numbers & Rates \\
\hline East Coast Area & 189 & 71.7 & 5,179 & $1,964.7$ & II,987 & $4,547.3$ \\
\hline Northern Area & 115 & 29.9 & $\mathrm{I}, 246$ & 324.3 & 11,816 & $3,075.2$ \\
\hline South Western Area & 119 & 26.2 & 2,088 & 459.9 & $|5,80|$ & $3,480.0$ \\
\hline Midlands Area & 20 & 11.7 & 514 & 300.3 & 9,488 & $5,543.8$ \\
\hline Mid Western Area & 199 & 75.9 & 2,770 & $1,056.2$ & $4 I, 458$ & $15,808.6$ \\
\hline North Eastern Area & 25 & 9.7 & 113 & 43.9 & 5,682 & $2,208.4$ \\
\hline North Western Area & 50 & 29.6 & 447 & 264.7 & 8,118 & $4,807.3$ \\
\hline South Eastern Area & 66 & 20.5 & 2,303 & 713.7 & 24,089 & $7,464.7$ \\
\hline Southern Area & 169 & 37.5 & 2,279 & 505.5 & 22,462 & $4,982.1$ \\
\hline Western Area & 70 & 23.8 & 2,171 & 738.7 & 11,332 & $3,855.9$ \\
\hline Total & 1,022 & 33.7 & 19,110 & 630.9 & 162,233 & $5,356.2$ \\
\hline
\end{tabular}

*There were incomplete returns from some areas. 
Activity and catchment area characteristics 2004

\section{Day centres}

A day centre usually provides social care for service users, with an emphasis on rehabilitation and activation services. The wide variety of activity that goes on in day centres is not captured by simple measures of attendance. As with other elements of the mental health services, there is no information captured on the various mental health professionals involved in this activity, or the characteristics of day centre attendees. This type of information will be required in the future.

In 2004 there were 106 day centres providing a total of 2,486 places, a rate of 82.1 places per 100,000 population over 16 (Table 3). There were just over 9,000 persons attending these day centres, with a total of 413,771 attendances. Unfortunately, some areas did not provide complete returns for day centres thus it is difficult to make reliable comparisons. As with other parts of the community mental health services, there are wide disparities in provision and activity.

Table 3: Day centres by HSE Area. Ireland 2004.

Numbers with rates per 100,000 population aged 16 years and over.*

\begin{tabular}{|c|c|c|c|c|c|c|}
\hline \multirow[b]{2}{*}{ HSE Area } & \multicolumn{2}{|l|}{ Places } & \multicolumn{2}{|c|}{ Attendances } & \multicolumn{2}{|c|}{ Persons Attending } \\
\hline & Numbers & Rates & Numbers & Rates & Numbers & Rates \\
\hline East Coast Area & 330 & 125.2 & 41,538 & $15,757.4$ & 182 & 69.0 \\
\hline Northern Area & 167 & 43.5 & 25,228 & $6,565.8$ & $\mathrm{I}, 254$ & 326.4 \\
\hline South Western Area & 92 & 20.3 & 12,387 & $2,728.1$ & 1,536 & 338.3 \\
\hline Midlands Area & 36 & 21.0 & 35,400 & $20,684.0$ & 399 & 233.1 \\
\hline Mid Western Area & 210 & 80.1 & 46,253 & 17,637.| & 434 & 165.5 \\
\hline North Eastern Area & 220 & 85.5 & 42,048 & $16,342.6$ & $|, 57|$ & 610.6 \\
\hline North Western Area & 370 & 219.1 & 58,251 & $34,495.2$ & 538 & 318.6 \\
\hline South Eastern Area & 194 & 60.1 & $|7,65|$ & $5,469.7$ & 295 & 91.4 \\
\hline Southern Area & 352 & 78.1 & $5 I, 666$ & II,459.7 & 1,921 & 426.1 \\
\hline Western Area & 515 & 175.2 & 83,349 & $28,360.6$ & 919 & 312.7 \\
\hline Total & 2,486 & 82.1 & $4|3,77|$ & $13,660.8$ & 9,049 & 298.8 \\
\hline
\end{tabular}

*There were incomplete returns from some areas. 


\section{Community residences}

Community Residences were defined as follows:
24 HOUR STAFFED COMMUNITY RESIDENCES: akin to community
residences previously described as high support where 24 hour in situ
supervised care for service users is provided.
DAY ONLY or NIGHT ONLY STAFFED COMMUNITY RESIDENCES: akin to
community residences previously described as medium support, where day
only or night only in situ supervised care for service users is provided.
VISITING STAFF ONLY: akin to community residences previously described as
low support, where nursing staff visit the residence on a frequent basis but
there is no in situ supervised care for service users.

The number of residents in community residences was collected in 2004, for each level of support. Table 4 shows there was a total of 3,065 residents in 2004, a rate of 101.2 per 100,000 population over 16 years. Fifty per cent of residents were in high support community residences, with $20.4 \%$ in medium support residences and $29.6 \%$ in low support residences. There is considerable variation in the provision of community residential places across HSE areas, with the highest rate in the HSE North Western Area (197.8 residents per 100,000 population over 16) and the lowest rate of provision in the HSE South Western Area (a rate of 47.8 residents), which represents a four-fold variation.

The number of community residential places in 2003 was 3,146 (a rate of 103.9). Given the fact that residents (not places) was measured in 2004, this probably represents a position of 'no change', as some places may have been vacant when the figures were collected.

As measured by admissions and discharges, there was a relatively low level of activity associated with community residences. This is because many community residences are effectively a home for many residents, and consequently there is a relatively low turnover of places in some residences. There was a total of 1,270 admissions to community residences in 2004 (a rate of 41.9 per 100,000 population aged 16 years and over) and 1,114 discharges (see Tables 5, 6 and 7 in Appendix 2 for details). These numbers show an increase on 2003, when there were 1,187 admissions and 1,175 discharges. The HSE North Western area had the highest rate of admissions (178.2) while the HSE Southern Area had the lowest rate (8.4). 
Activity and catchment area characteristics 2004

Table 4 Community residences: Residents by HSE Area (former health board area). Ireland 2004. Numbers with rates per 100,000 aged 16 and over

\begin{tabular}{|c|c|c|c|c|c|c|c|c|}
\hline \multirow[b]{2}{*}{ HSE Area } & \multicolumn{2}{|c|}{ Low Support } & \multicolumn{2}{|c|}{ Medium Support } & \multicolumn{2}{|c|}{ High Support } & \multicolumn{2}{|l|}{ Total } \\
\hline & $\begin{array}{l}\text { Number of } \\
\text { residents }\end{array}$ & Rates & $\begin{array}{l}\text { Number of } \\
\text { residents }\end{array}$ & Rates & $\begin{array}{l}\text { Number of } \\
\text { residents }\end{array}$ & Rates & $\begin{array}{l}\text { Number of } \\
\text { residents }\end{array}$ & Rates \\
\hline $\begin{array}{l}\text { East Coast } \\
\text { Area }\end{array}$ & 62 & 23.5 & 41 & 15.6 & 68 & 25.8 & 171 & 64.9 \\
\hline $\begin{array}{l}\text { Northern } \\
\text { Area }\end{array}$ & 91 & 23.7 & 97 & 25.2 & 227 & 59.1 & 415 & 108.0 \\
\hline $\begin{array}{l}\text { South } \\
\text { Western } \\
\text { Area }\end{array}$ & 61 & 13.4 & 62 & 13.7 & 94 & 20.7 & 217 & 47.8 \\
\hline $\begin{array}{l}\text { Midlands } \\
\text { Area }\end{array}$ & 84 & 49.1 & 37 & 21.6 & 64 & 37.4 & 185 & 108.1 \\
\hline $\begin{array}{l}\text { Mid } \\
\text { Western } \\
\text { Area }\end{array}$ & 38 & 14.5 & 66 & 25.2 & 235 & 89.6 & 339 & 129.3 \\
\hline $\begin{array}{l}\text { North } \\
\text { Eastern } \\
\text { Area }\end{array}$ & 55 & 21.4 & 6 & 2.3 & 132 & 51.3 & 193 & 75.0 \\
\hline $\begin{array}{l}\text { North } \\
\text { Western } \\
\text { Area }\end{array}$ & 95 & 56.3 & 61 & 36.1 & 178 & 105.4 & 334 & 197.8 \\
\hline $\begin{array}{l}\text { South } \\
\text { Eastern } \\
\text { Area }\end{array}$ & $13 \mid$ & 40.6 & 106 & 32.8 & 184 & 57.0 & 421 & 130.4 \\
\hline $\begin{array}{l}\text { Southern } \\
\text { Area }\end{array}$ & 112 & 24.8 & 12 & 2.7 & 206 & 45.7 & 330 & 73.2 \\
\hline $\begin{array}{l}\text { Western } \\
\text { Area }\end{array}$ & 176 & 59.9 & 138 & 47.0 & 146 & 49.7 & 460 & 156.5 \\
\hline Total & 905 & 29.9 & 626 & 20.7 & 1,534 & 50.6 & 3,065 & 101.2 \\
\hline
\end{tabular}




\section{Information on other mental health services}

In the 2004 community mental health services activity form, narrative sections were provided for the collection of information on child and adolescent mental health services, mental health services for people with intellectual disability and other mental health services. It was not possible to collect standardised information on these services as no systems are in place for this and the management and structure of these services varies considerably.

\section{Later Life mental health services}

Information received in this area varied from service to service. Some services combined details of later life services with general adult services, while others provided separate information. From the separate information provided there were 7 dedicated services for later life in day hospitals, with 7,777 attendances and approximately 2,000 persons attended day clinics for later life. Most of these services are managed by mental health. It must be stressed however that this does not give a comprehensive picture of activity in this area.

\section{Child and adolescent mental health services (CAMHS)}

National information collection on CAMHS has focused on inpatient activity, namely admissions to the Children's Centres reported each year in the HRB Activities reports. In addition, the admissions of those under 16 years to adult psychiatric hospitals and units is reported.

However, the majority of activity in CAMHS is carried on by multidisciplinary mental health teams based in the community. There is no nationally collected information on these services. The reporting situation is complicated by the fact that some CAMHS are managed by community care rather than mental health. As for all mental health services, there should be an agreed minimum data set, with agreed definitions, for CAMHS. This data set should collect information on the infrastructure through which CAMHS are delivered, and the activity of these services.

\section{Mental health services for people with intellectual disability}

The National Intellectual Disability Database (Mulvaney and Barron, 2005) ${ }^{4}$ collects information on all individuals in Ireland with an intellectual disability who are in receipt of intellectual disability services. However, there is only

4 National Intellectual Disability Database Committee Annual Report 2005, Barren, S. and Mulvany, F. (2005) Health Research Board, Dublin 
Activity and catchment area characteristics 2004

limited data collected on mental health service provision as part of this database. The provision of mental health services for people with intellectual disability varies nationally, with many areas having no specialist mental health service for intellectual disability, and a limited provision of such services elsewhere. In addition, mental health services for people with intellectual disability are managed by local mental health services, community care or voluntary services, depending on the provider.

Other mental health services

A number of other specialist mental health services are provided in some areas, such as liaison mental health services, substance misuse mental health services and mental health services for the homeless. There is no standard data collection system in place to capture the activity of these services.

\section{Future developments}

The remit of the Mental Health Commission covers all mental health services. Traditionally, data collection has focused on adult mental health services and while there are still improvements to be made in information coming from these services, systems are fairly well developed. Data collection from other mental health services is largely non-existent. A data set with agreed definitions needs to be developed, along with information systems, so that the activity of these mental health services can be recorded to assist in planning and evaluation. 


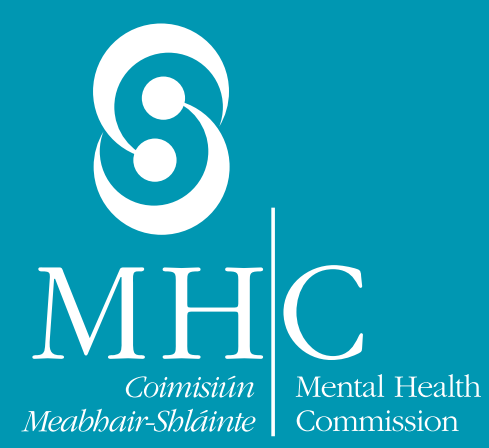

Part 2 
Activity and catchment area characteristics 2004

\section{Part II: Mental health catchment area profiles}

\section{Deprivation}

There are 3,422 electoral divisions (EDs) in Ireland, and detailed information on the demographic profile of each ED is available from the Central Statistics Office. Using this information, the age profile of each mental health catchment area was provided in the Annual Report of the Mental Health Commission 2004. Other information available at ED level has been used by the Small Area Health Research Unit (SAHRU) in Trinity College, to develop an Irish index of deprivation. The material deprivation of each electoral division in Ireland is measured on a scale of 1 to 10 , with 1 being the most affluent and 10 the most disadvantaged. The scale takes into account the following 5 indicators, unemployment, low social class, no car, type of housing tenure, and overcrowding (Kelly and Teljeur 2004)5. A statistical technique called principle components analysis is used to construct a weighted combination of these indicators.

\section{Interpretation of tables and maps}

For each mental health catchment area the following maps and tables show the number of EDs at each level of the index in the catchment area, the population residing in those EDs, and the proportion of the catchment area population which resides in the EDs at each level of the index.

It must be stressed that not everyone living in an electoral division with a score of 1 is affluent and not everyone living in an electoral division with a score of 10 is disadvantaged. Therefore the index is best used to describe a total population in percentage terms, e.g. we can say that $6 \%$ of the population of the East Coast Area reside in electoral divisions with a score of 10, (the most disadvantaged EDs), but we cannot say that the 21,000 people who reside in these electoral divisions are all disadvantaged. The index is best used to give an overall description of the mental health catchment areas and is very useful in this way for planning services. It has been shown to be predictive of health outcomes and health service demands (Kelly and Teljeur 2004).

5 A New National Deprivation Index for Health and Health Services Research. Short Report, Kelly, A., Teljeur C. 2004 Small Area Health Research Unit, Department of Public Health \& Primary Care, Trinity College Dublin 
Persons living in electoral divisions nationally by level of deprivation

\begin{tabular}{|r|r|r|r|}
\hline $\begin{array}{l}\text { SAHRU Deprivation } \\
\text { Index (2002) }\end{array}$ & $\begin{array}{l}\text { No. of Electoral } \\
\text { Divisions }\end{array}$ & $\begin{array}{l}\text { National } \\
\text { Population }\end{array}$ & \multicolumn{2}{l|}{$\begin{array}{l}\text { National } \\
\text { Population }\end{array}$} \\
\hline 1 & 342 & 588,838 & 15.0 \\
\hline 2 & 342 & 337,162 & 8.6 \\
\hline 3 & 342 & 344,895 & 8.8 \\
\hline 4 & 342 & 248,302 & 6.3 \\
\hline 5 & 342 & 257,607 & 6.6 \\
\hline 6 & 343 & 289,236 & 7.4 \\
\hline 7 & 342 & 289,244 & 7.4 \\
\hline 8 & 342 & 396,459 & 10.1 \\
\hline 9 & 342 & 473,437 & 12.1 \\
\hline 10 & 343 & 692,023 & 17.1 \\
\hline Total & & $3,917,203$ & \\
\hline
\end{tabular}

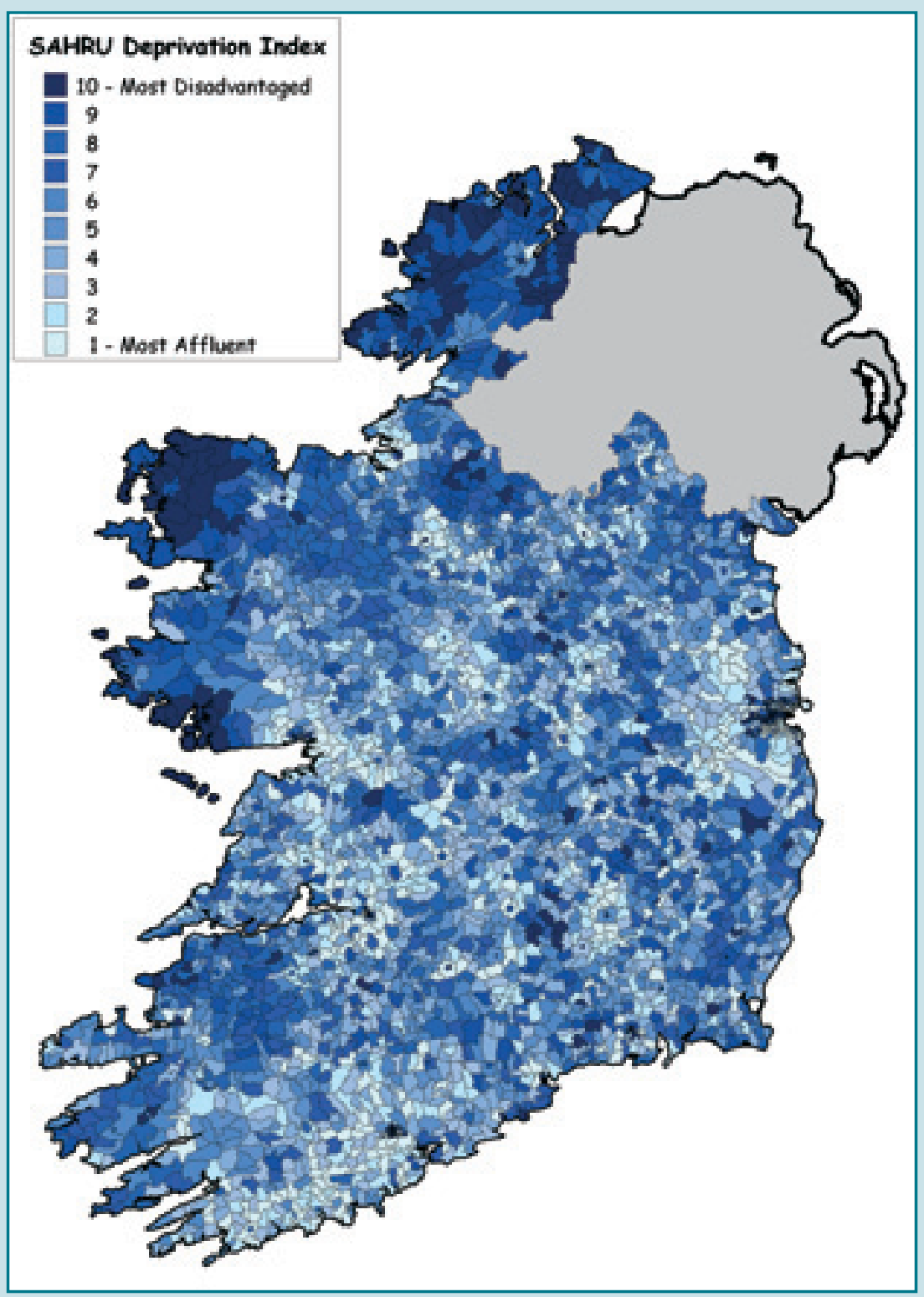


HSE - East Coast Area

Persons living in Cluain Mhuire Mental Health Catchment Area 1 by level of deprivation

\begin{tabular}{|r|r|r|r|}
\hline \begin{tabular}{l} 
SAHRU $\begin{array}{l}\text { Deprivation } \\
\text { Index (2002) }\end{array}$ \\
\hline 1
\end{tabular} & $\begin{array}{l}\text { No. of Electoral } \\
\text { Divisions }\end{array}$ & $\begin{array}{l}\text { Catchment Area } \\
\text { Population }\end{array}$ & $\begin{array}{l}\text { \% Catchment } \\
\text { Area Population }\end{array}$ \\
\hline 2 & 35 & 95,191 & $55.91 \%$ \\
\hline 3 & 5 & 22,606 & $13.28 \%$ \\
\hline 4 & 2 & 7,100 & $4.17 \%$ \\
\hline 5 & 3 & 9,062 & $5.32 \%$ \\
\hline 6 & 2 & 6,511 & $3.82 \%$ \\
\hline 7 & 2 & 4,052 & $2.38 \%$ \\
\hline 8 & 1 & 2,700 & $1.59 \%$ \\
\hline 9 & 1 & 3,258 & $1.91 \%$ \\
\hline 10 & 2 & 3,503 & $2.06 \%$ \\
\hline Total & 5 & 16,279 & $9.56 \%$ \\
\hline & 58 & 170,262 & \\
\hline
\end{tabular}

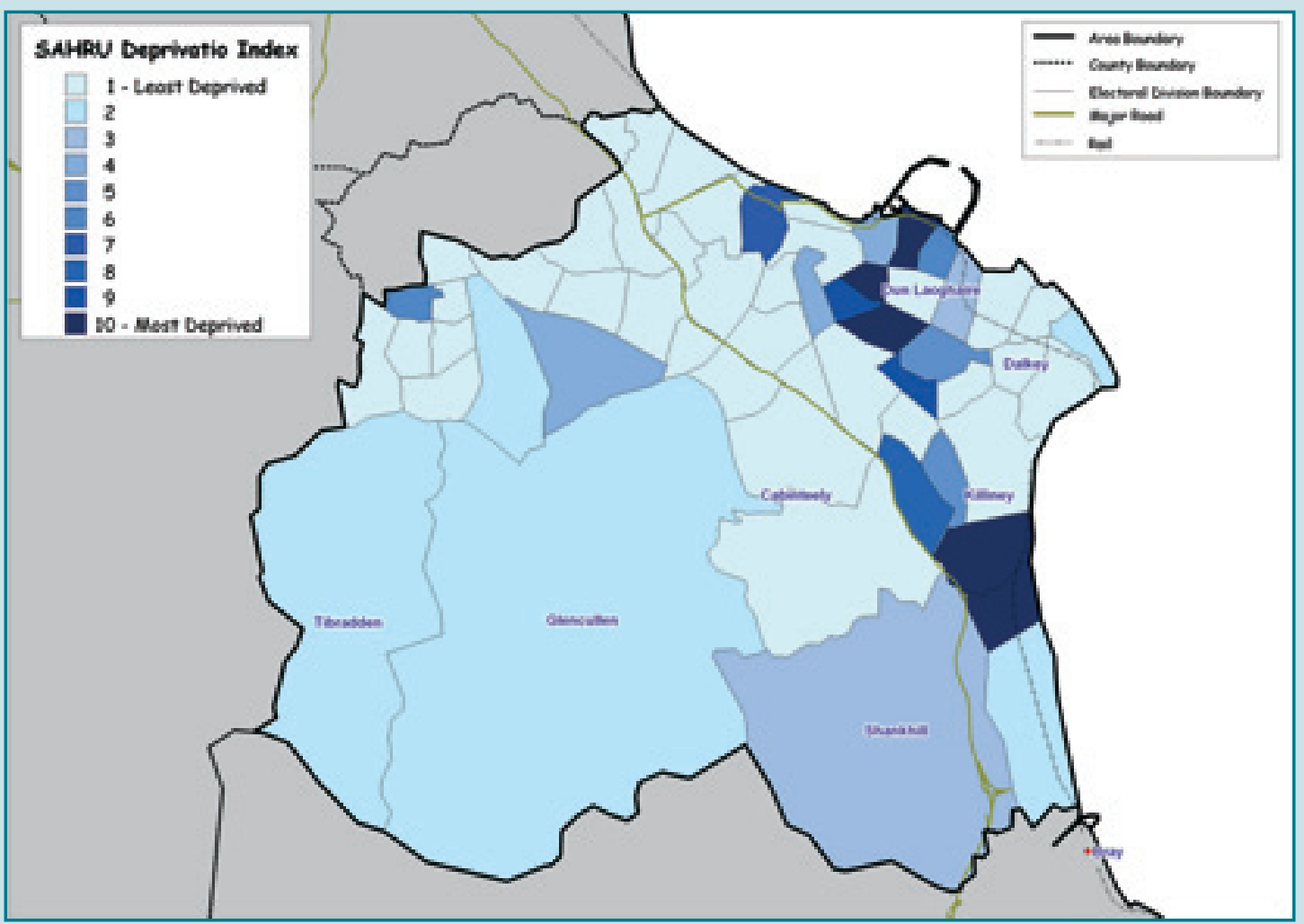


Persons living in Mental Health Catchment Area 2 by level of deprivation

\begin{tabular}{|c|c|c|c|}
\hline $\begin{array}{l}\text { SAHRU } \\
\text { Deprivation } \\
\text { Index (2002) }\end{array}$ & $\begin{array}{l}\text { No. of Electoral } \\
\text { Divisions }\end{array}$ & $\begin{array}{l}\text { Catchment Area } \\
\text { Population }\end{array}$ & $\begin{array}{l}\text { \% Catchment } \\
\text { Area Population }\end{array}$ \\
\hline I & II & 29,790 & $29.50 \%$ \\
\hline 2 & 3 & 10,005 & $9.91 \%$ \\
\hline 3 & I & 4,188 & $4.15 \%$ \\
\hline 4 & 0 & 0 & $0.00 \%$ \\
\hline 5 & 3 & 6,995 & $6.93 \%$ \\
\hline 6 & 2 & 7,782 & $7.71 \%$ \\
\hline 7 & 1 & 2,084 & $2.06 \%$ \\
\hline 8 & 0 & 0 & $0.00 \%$ \\
\hline 9 & 4 & 7,510 & $7.44 \%$ \\
\hline 10 & 10 & 32,619 & $32.30 \%$ \\
\hline Total & 35 & $100,973 *$ & \\
\hline
\end{tabular}

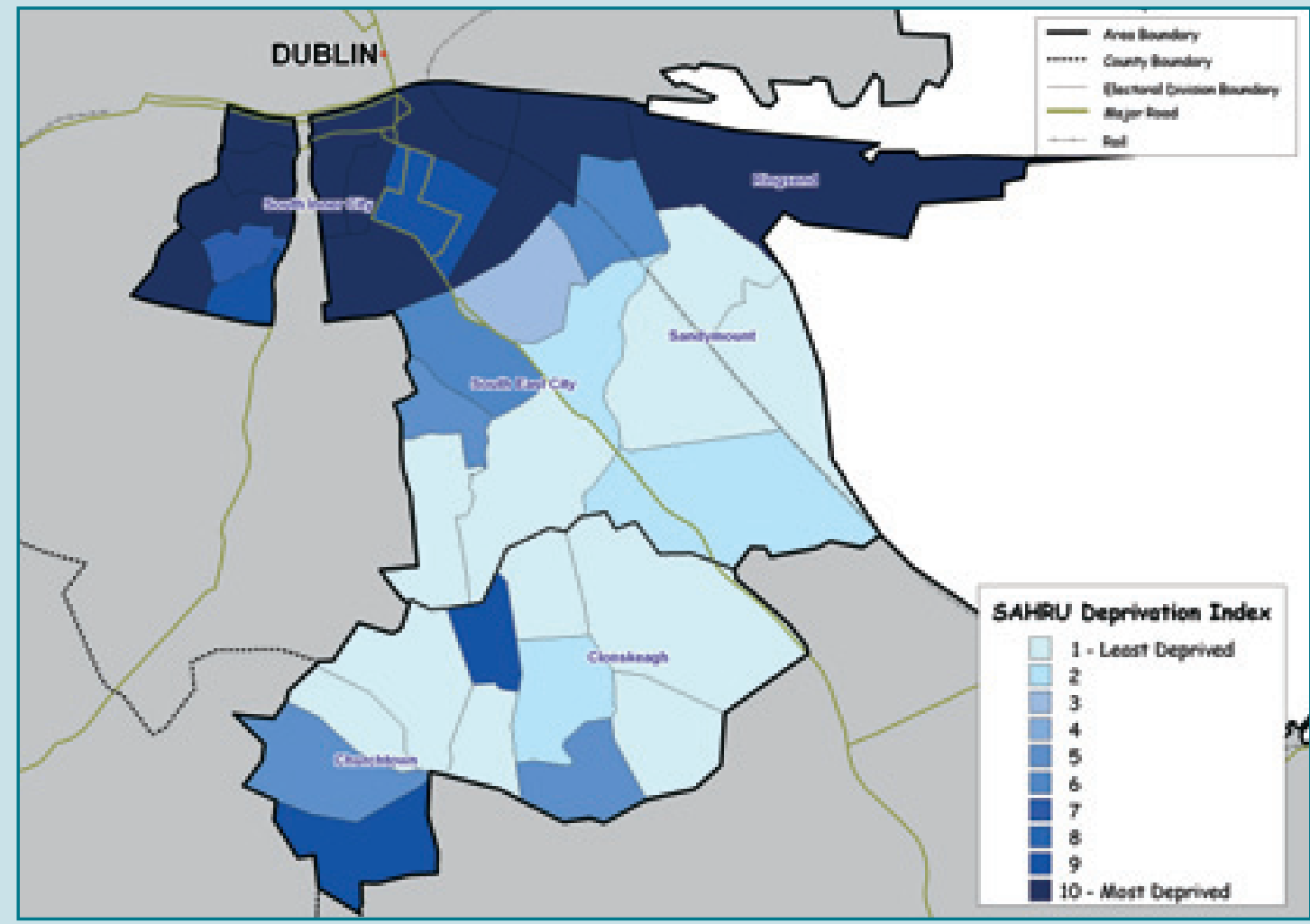

* The population provided for Area 2 is approximate as electoral divisions are split with Mental Health Catchment Area 3 
Persons living in Mental Health Catchment Area 10 by level of deprivation

\begin{tabular}{|r|r|r|r|}
\hline $\begin{array}{l}\text { SAHRU } \\
\text { Deprivation } \\
\text { Index (2002) }\end{array}$ & $\begin{array}{l}\text { No. of Electoral } \\
\text { Divisions }\end{array}$ & $\begin{array}{l}\text { Catchment Area } \\
\text { Population }\end{array}$ & $\begin{array}{l}\text { \% Catchment } \\
\text { Area Population }\end{array}$ \\
\hline 1 & 5 & 9,460 & $9.45 \%$ \\
\hline 2 & 7 & 10,339 & $10.33 \%$ \\
\hline 3 & 5 & 3,096 & $3.09 \%$ \\
\hline 4 & 5 & 2,080 & $2.08 \%$ \\
\hline 5 & 5 & 12,302 & $12.29 \%$ \\
\hline 6 & 5 & 5,371 & $5.37 \%$ \\
\hline 7 & 7 & 25,667 & $25.64 \%$ \\
\hline 8 & 10 & 14,086 & $14.07 \%$ \\
\hline 9 & 6 & 12,985 & $12.97 \%$ \\
\hline 10 & 4 & 4,719 & $4.71 \%$ \\
\hline Total & 59 & 100,105 & \\
\hline
\end{tabular}

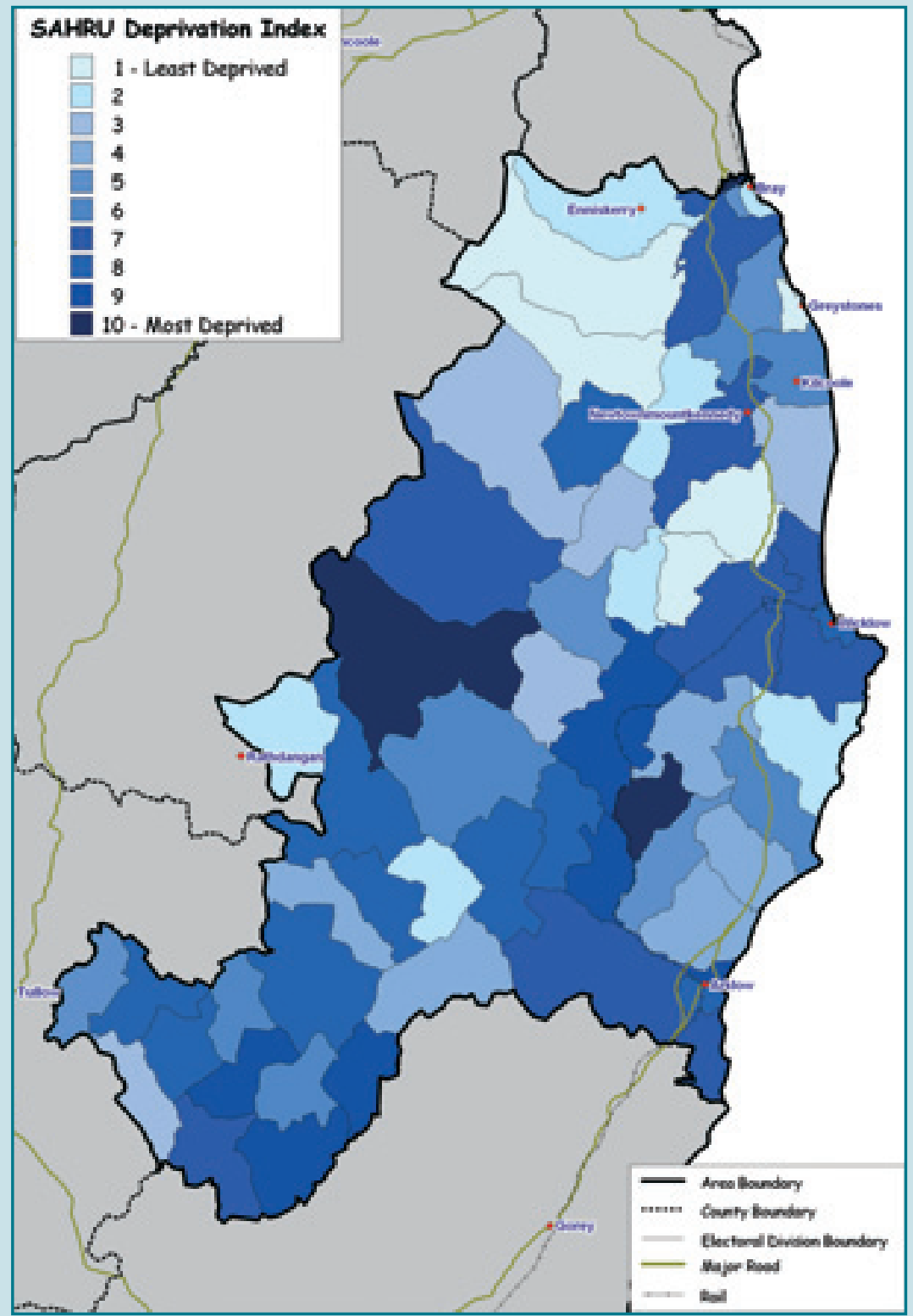


HSE - South Western Area

Persons living in Mental Health Catchment Area 3 by level of deprivation

\begin{tabular}{|r|r|r|r|}
\hline \begin{tabular}{l} 
SAHRU $\begin{array}{l}\text { Deprivation } \\
\text { Index (2002) }\end{array}$ \\
\hline 1
\end{tabular} & $\begin{array}{l}\text { No. of Electoral } \\
\text { Divisions }\end{array}$ & $\begin{array}{l}\text { Catchment Area } \\
\text { Population }\end{array}$ & $\begin{array}{l}\text { \% Catchment } \\
\text { Area Population }\end{array}$ \\
\hline 2 & 12 & 43,620 & $32.77 \%$ \\
\hline 3 & 0 & 0 & $0.00 \%$ \\
\hline 4 & 1 & 3,494 & $2.63 \%$ \\
\hline 5 & 1 & 3,569 & $2.68 \%$ \\
\hline 6 & 2 & 6,120 & $4.60 \%$ \\
\hline 7 & 1 & 2,929 & $2.20 \%$ \\
\hline 8 & 1 & 2,084 & $1.57 \%$ \\
\hline 9 & 2 & 8,910 & $6.69 \%$ \\
\hline 10 & 5 & 14,212 & $10.68 \%$ \\
\hline Total & 17 & 48,157 & $36.18 \%$ \\
\hline
\end{tabular}

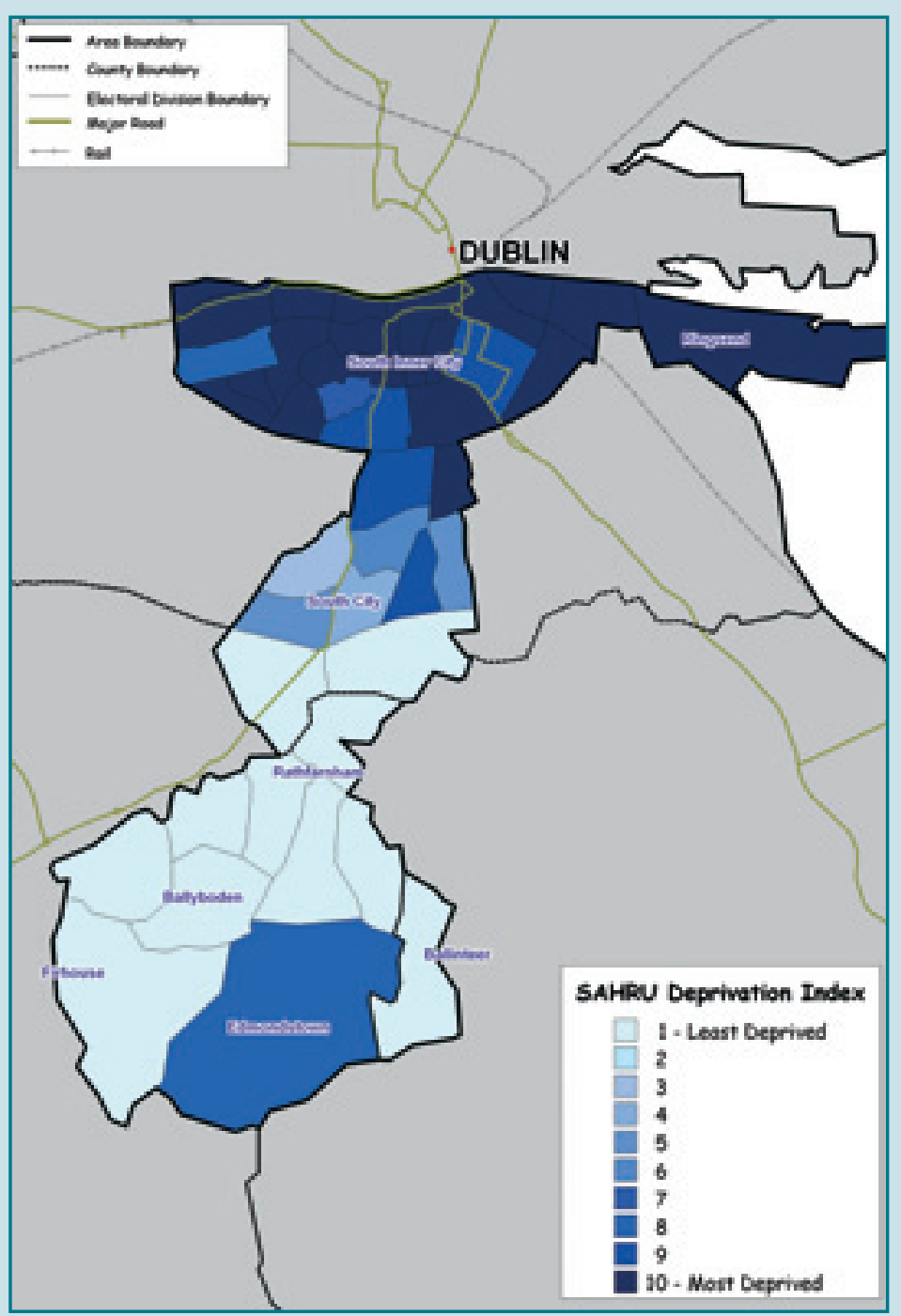

* The population provided for Area 3 is approximate as electoral divisions are split with Mental Health Catchment Area 2 
Persons living in Mental Health Catchment Area 4 Q 5 by level of deprivation

\begin{tabular}{|r|r|r|r|}
\hline \begin{tabular}{l} 
SAHRU $\begin{array}{l}\text { Deprivation } \\
\text { Index (2002) }\end{array}$ \\
\hline 1
\end{tabular} & $\begin{array}{l}\text { No. of Electoral } \\
\text { Divisions }\end{array}$ & $\begin{array}{l}\text { Catchment Area } \\
\text { Population }\end{array}$ & $\begin{array}{l}\text { \% Catchment } \\
\text { Area Population }\end{array}$ \\
\hline 2 & 7 & 38,296 & $15.79 \%$ \\
\hline 3 & 4 & 17,536 & $7.23 \%$ \\
\hline 4 & 7 & 26,931 & $11.10 \%$ \\
\hline 5 & 1 & 9,363 & $3.86 \%$ \\
\hline 6 & 3 & 4,103 & $1.69 \%$ \\
\hline 7 & 3 & 18,498 & $7.62 \%$ \\
\hline 8 & 3 & 8,864 & $3.65 \%$ \\
\hline 9 & 3 & 9,349 & $3.85 \%$ \\
\hline 10 & 3 & 10,987 & $4.53 \%$ \\
\hline Total & 23 & 98,683 & $40.68 \%$ \\
\hline & 57 & 242,610 & \\
\hline
\end{tabular}

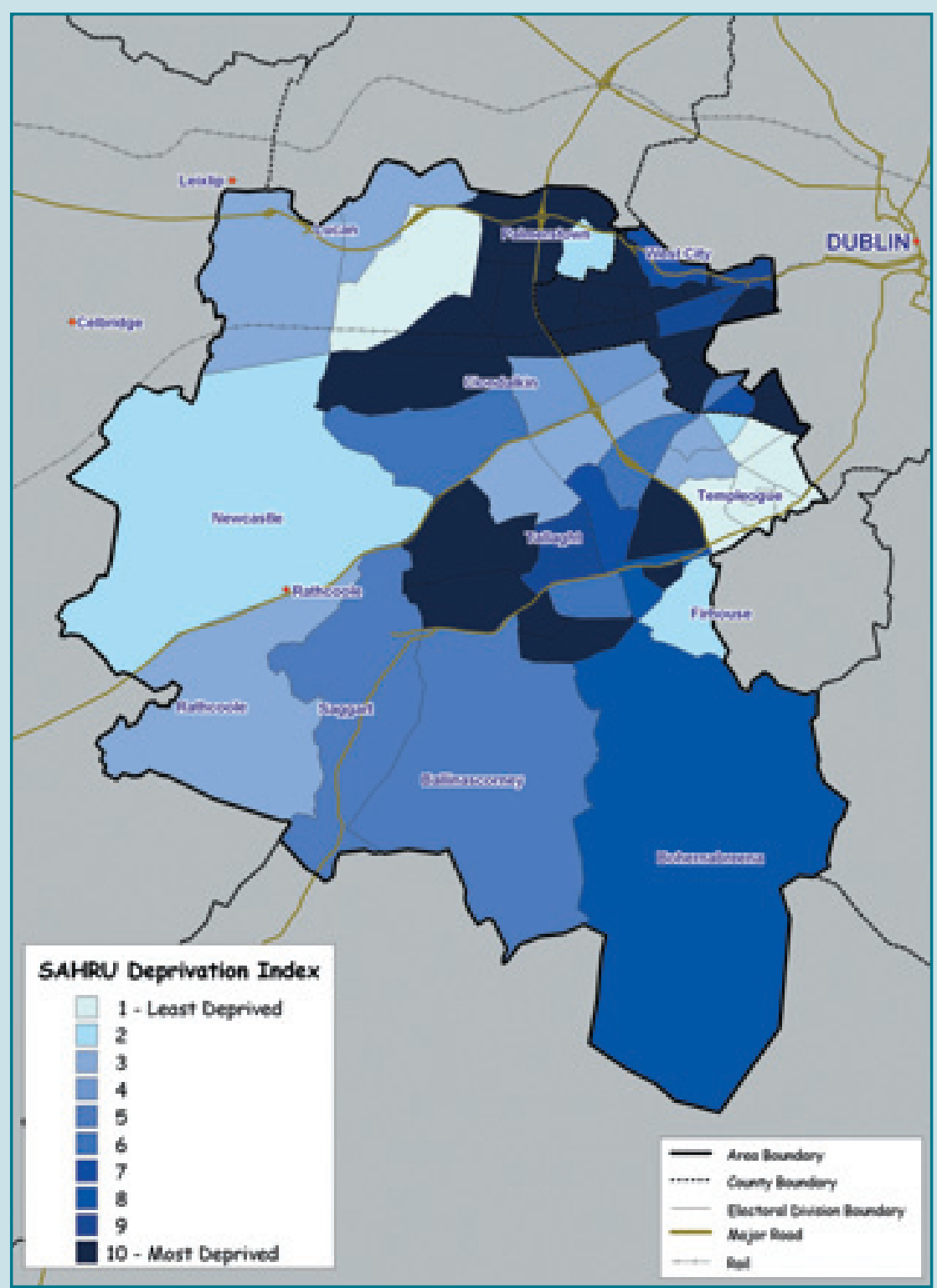


Persons living in Mental Health Catchment Area o by level of deprivation

\begin{tabular}{|c|c|c|c|}
\hline $\begin{array}{l}\text { SAHRU } \\
\text { Deprivation } \\
\text { Index (2002) }\end{array}$ & $\begin{array}{l}\text { No. of Electoral } \\
\text { Divisions }\end{array}$ & $\begin{array}{l}\text { Catchment Area } \\
\text { Population }\end{array}$ & $\begin{array}{l}\% \text { Catchment } \\
\text { Area Population }\end{array}$ \\
\hline I & 13 & $|I, 52|$ & $6.45 \%$ \\
\hline 2 & 17 & $32,67 \mid$ & $18.30 \%$ \\
\hline 3 & 18 & 66,001 & $36.97 \%$ \\
\hline 4 & 10 & 10,012 & $5.61 \%$ \\
\hline 5 & 6 & 2,272 & $1.27 \%$ \\
\hline 6 & 7 & 4,092 & $2.29 \%$ \\
\hline 7 & 10 & 4,201 & $2.35 \%$ \\
\hline 8 & 10 & 10,292 & $5.77 \%$ \\
\hline 9 & 18 & 34,059 & $19.08 \%$ \\
\hline 10 & 3 & 3,394 & $1.90 \%$ \\
\hline Total & 112 & 178,5 I 5 & \\
\hline
\end{tabular}

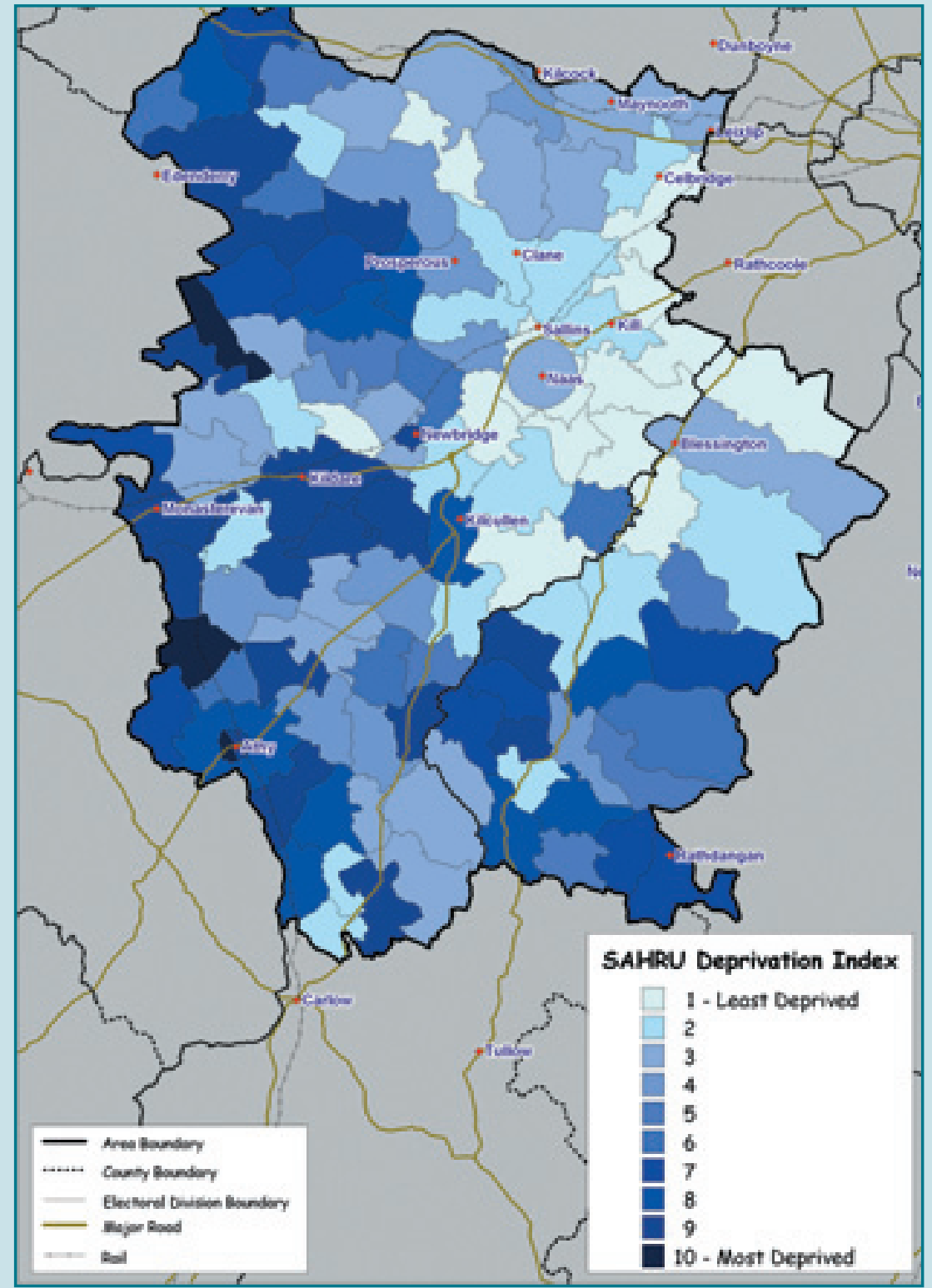


HSE - Northern Area

Persons living in Mental Health Catchment Area 6 by level of deprivation

\begin{tabular}{|r|r|r|r|}
\hline \begin{tabular}{l} 
SAHRU $\begin{array}{l}\text { Deprivation } \\
\text { Index (2002) }\end{array}$ \\
\hline 1
\end{tabular} & $\begin{array}{l}\text { No. of Electoral } \\
\text { Divisions }\end{array}$ & $\begin{array}{l}\text { Catchment Area } \\
\text { Population }\end{array}$ & $\begin{array}{l}\text { \% Catchment } \\
\text { Area Population }\end{array}$ \\
\hline 2 & 4 & 21,801 & $15.24 \%$ \\
\hline 3 & 5 & 19,579 & $13.69 \%$ \\
\hline 4 & 2 & 5,095 & $3.56 \%$ \\
\hline 5 & 1 & 24,404 & $17.06 \%$ \\
\hline 6 & 0 & 0 & $0.00 \%$ \\
\hline 7 & 1 & 3,129 & $2.19 \%$ \\
\hline 8 & 3 & 7,702 & $5.38 \%$ \\
\hline 9 & 2 & 4,159 & $2.91 \%$ \\
\hline 10 & 2 & 5,402 & $3.78 \%$ \\
\hline Total & 16 & 51,758 & $36.19 \%$ \\
\hline & 36 & 143,029 & \\
\hline
\end{tabular}

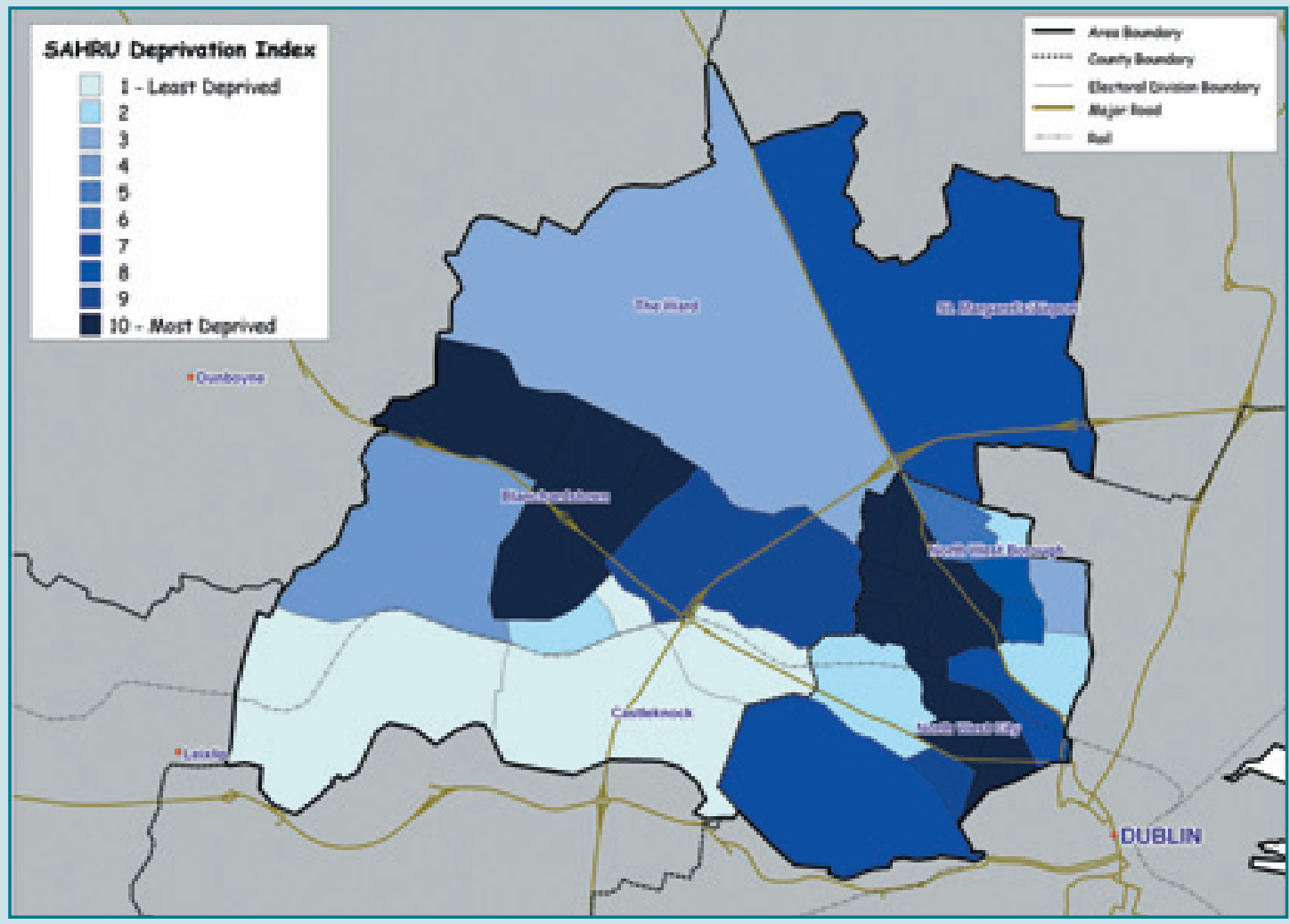


Persons living in Mental Health Catchment Area 7 by level of deprivation

\begin{tabular}{|r|r|r|r|}
\hline $\begin{array}{l}\text { SAHRU } \\
\begin{array}{l}\text { Deprivation } \\
\text { Index (2002) }\end{array}\end{array}$ & $\begin{array}{l}\text { No. of Electoral } \\
\text { Divisions }\end{array}$ & $\begin{array}{l}\text { Catchment Area } \\
\text { Population }\end{array}$ & $\begin{array}{l}\text { \% Catchment } \\
\text { Area Population }\end{array}$ \\
\hline 1 & 5 & 16,528 & $12.38 \%$ \\
\hline 2 & 5 & 15,101 & $11.31 \%$ \\
\hline 3 & 3 & 11,054 & $8.28 \%$ \\
\hline 4 & 1 & 5,986 & $4.48 \%$ \\
\hline 5 & 0 & 0 & $0.00 \%$ \\
\hline 6 & 5 & 12,842 & $9.62 \%$ \\
\hline 7 & 0 & 0 & $0.00 \%$ \\
\hline 8 & 0 & 0 & $0.00 \%$ \\
\hline 9 & 3 & 4,054 & $3.04 \%$ \\
\hline 10 & 21 & 67,994 & $50.91 \%$ \\
\hline Total & 43 & 133,559 & \\
\hline
\end{tabular}

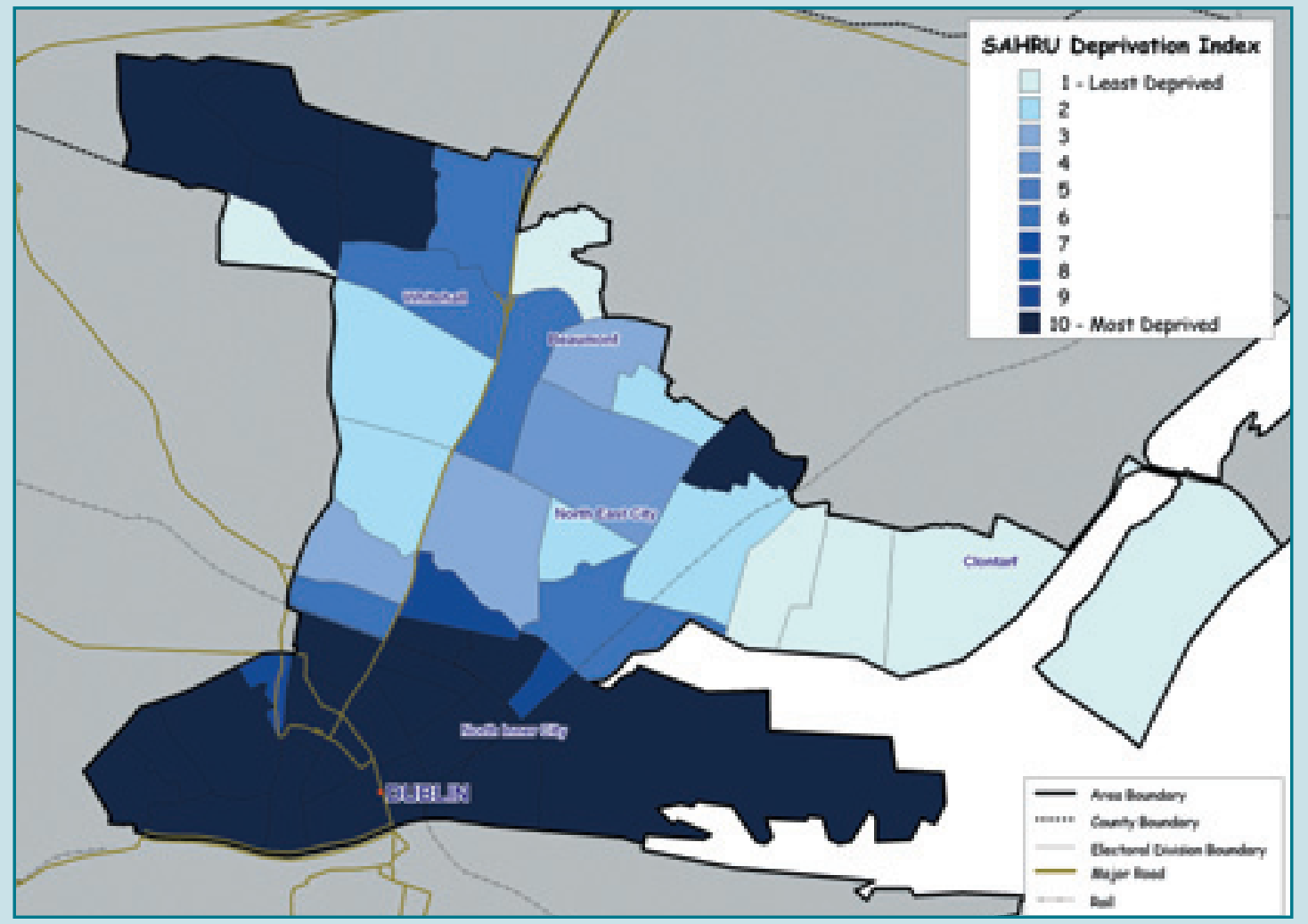


Persons living in Mental Health Catchment Area 8 by level of deprivation

\begin{tabular}{|r|r|r|r|}
\hline \begin{tabular}{l} 
SAHRU $\begin{array}{l}\text { Deprivation } \\
\text { Index (2002) }\end{array}$ \\
\hline 1
\end{tabular} & $\begin{array}{l}\text { No. of Electoral } \\
\text { Divisions }\end{array}$ & $\begin{array}{l}\text { Catchment Area } \\
\text { Population }\end{array}$ & $\begin{array}{l}\text { \% Catchment } \\
\text { Area Population }\end{array}$ \\
\hline 2 & 9 & 44,954 & $21.37 \%$ \\
\hline 3 & 3 & 12,274 & $5.84 \%$ \\
\hline 4 & 8 & 25,968 & $12.35 \%$ \\
\hline 5 & 6 & 21,570 & $10.25 \%$ \\
\hline 6 & 2 & 7,906 & $3.76 \%$ \\
\hline 7 & 4 & 14,179 & $6.74 \%$ \\
\hline 8 & 5 & 21,039 & $10.00 \%$ \\
\hline 9 & 5 & 23,913 & $11.37 \%$ \\
\hline 10 & 7 & 18,716 & $8.90 \%$ \\
\hline & 7 & 19,827 & $9.43 \%$ \\
\hline Total & 56 & 210,346 & \\
\hline
\end{tabular}

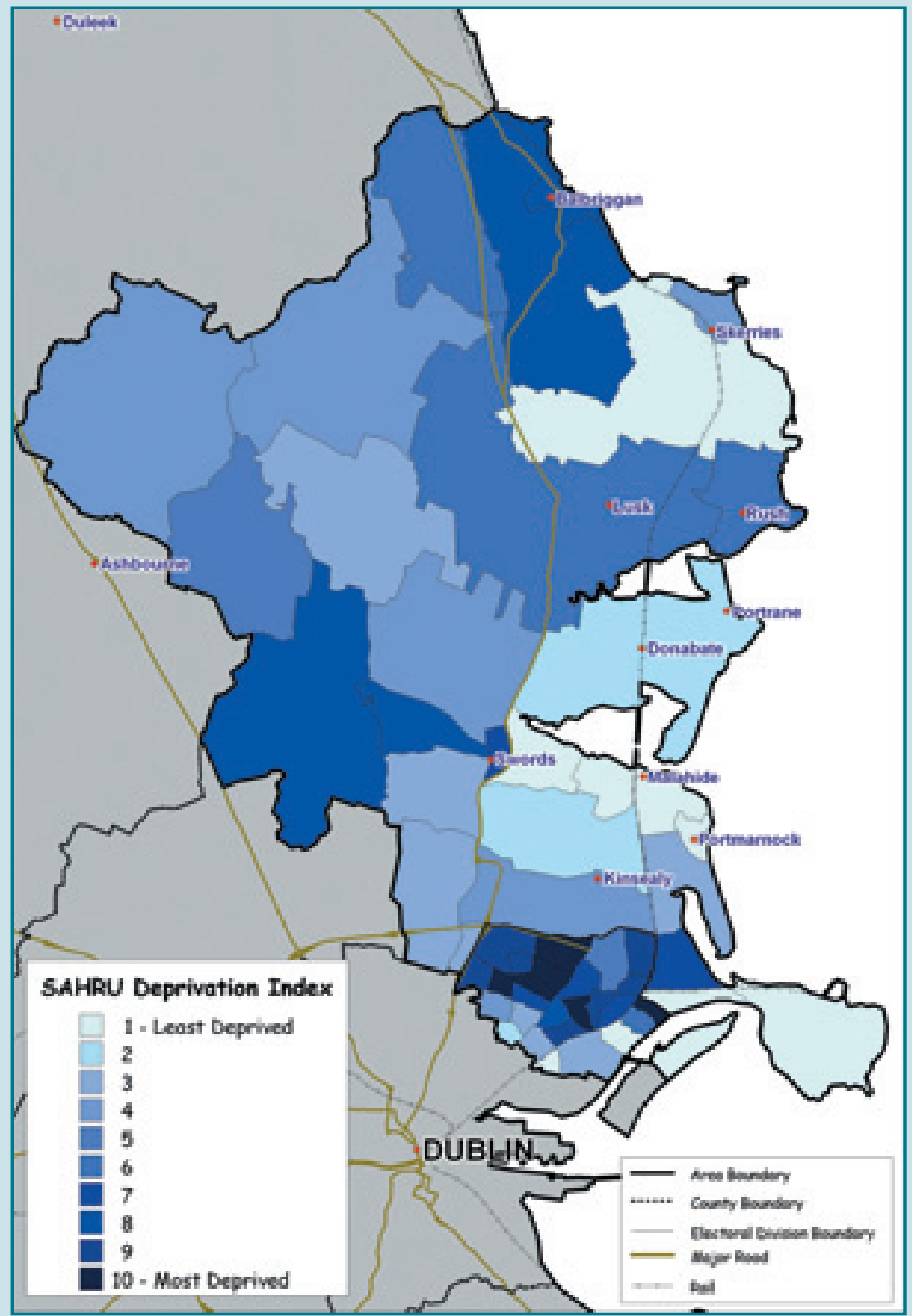


HSE - Mid Western Area

Persons living in Clare Mental Health Catchment Area by level of deprivation

\begin{tabular}{|r|r|r|r|}
\hline $\begin{array}{l}\text { SAHRU } \\
\text { Deprivation } \\
\text { Index (2002) }\end{array}$ & $\begin{array}{l}\text { No. of Electoral } \\
\text { Divisions }\end{array}$ & $\begin{array}{l}\text { Catchment Area } \\
\text { Population }\end{array}$ & $\begin{array}{l}\text { \% Catchment } \\
\text { Area Population }\end{array}$ \\
\hline 1 & 14 & 12,337 & $11.95 \%$ \\
\hline 2 & 31 & 25,049 & $24.25 \%$ \\
\hline 3 & 22 & 8,218 & $7.96 \%$ \\
\hline 4 & 17 & 5,244 & $5.08 \%$ \\
\hline 5 & 20 & 6,927 & $6.71 \%$ \\
\hline 6 & 13 & 5,652 & $5.47 \%$ \\
\hline 7 & 18 & 10,122 & $9.80 \%$ \\
\hline 8 & 6 & 12,868 & $12.46 \%$ \\
\hline 9 & 8 & 8,545 & $8.27 \%$ \\
\hline 10 & 4 & 8,315 & $8.05 \%$ \\
\hline Total & 153 & 103,277 & \\
\hline
\end{tabular}

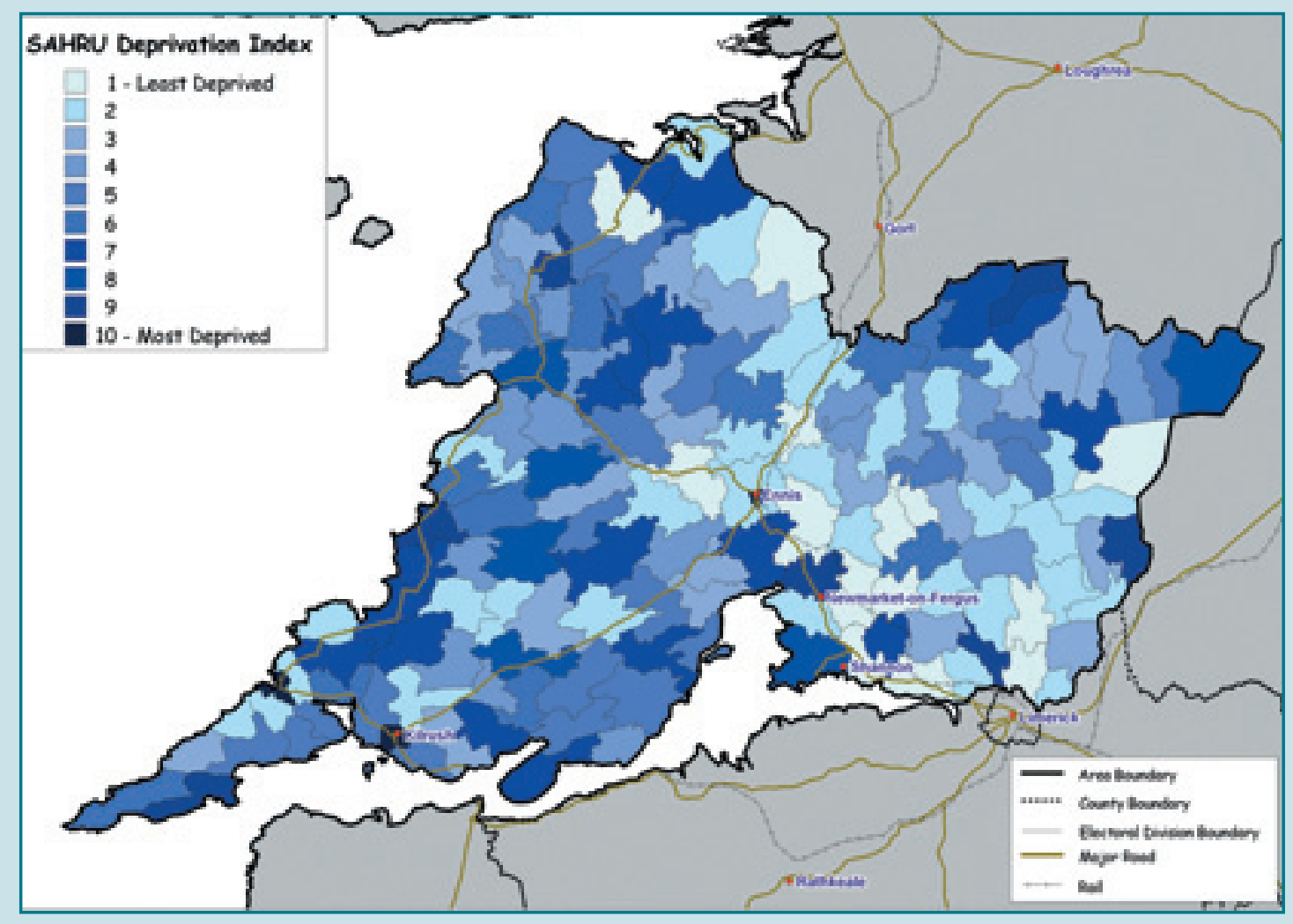


Persons living in Limerick Mental Health Catchment Area by level of deprivation

\begin{tabular}{|r|r|r|r|}
\hline $\begin{array}{l}\text { SAHRU } \\
\text { Deprivation } \\
\text { Index (2002) }\end{array}$ & $\begin{array}{l}\text { No. of Electoral } \\
\text { Divisions }\end{array}$ & $\begin{array}{l}\text { Catchment Area } \\
\text { Population }\end{array}$ & $\begin{array}{l}\text { \% Catchment } \\
\text { Area Population }\end{array}$ \\
\hline 1 & 20 & 48,142 & $27.46 \%$ \\
\hline 2 & 16 & 7,726 & $4.41 \%$ \\
\hline 3 & 15 & 6,589 & $3.76 \%$ \\
\hline 4 & 17 & 11,168 & $6.37 \%$ \\
\hline 5 & 14 & 6,452 & $3.68 \%$ \\
\hline 6 & 17 & 10,941 & $6.24 \%$ \\
\hline 7 & 13 & 13,609 & $7.76 \%$ \\
\hline 8 & 21 & 19,746 & $11.26 \%$ \\
\hline 9 & 15 & 20,287 & $11.57 \%$ \\
\hline 10 & 25 & 30,644 & $17.48 \%$ \\
\hline Total & 173 & 175,304 & \\
\hline
\end{tabular}

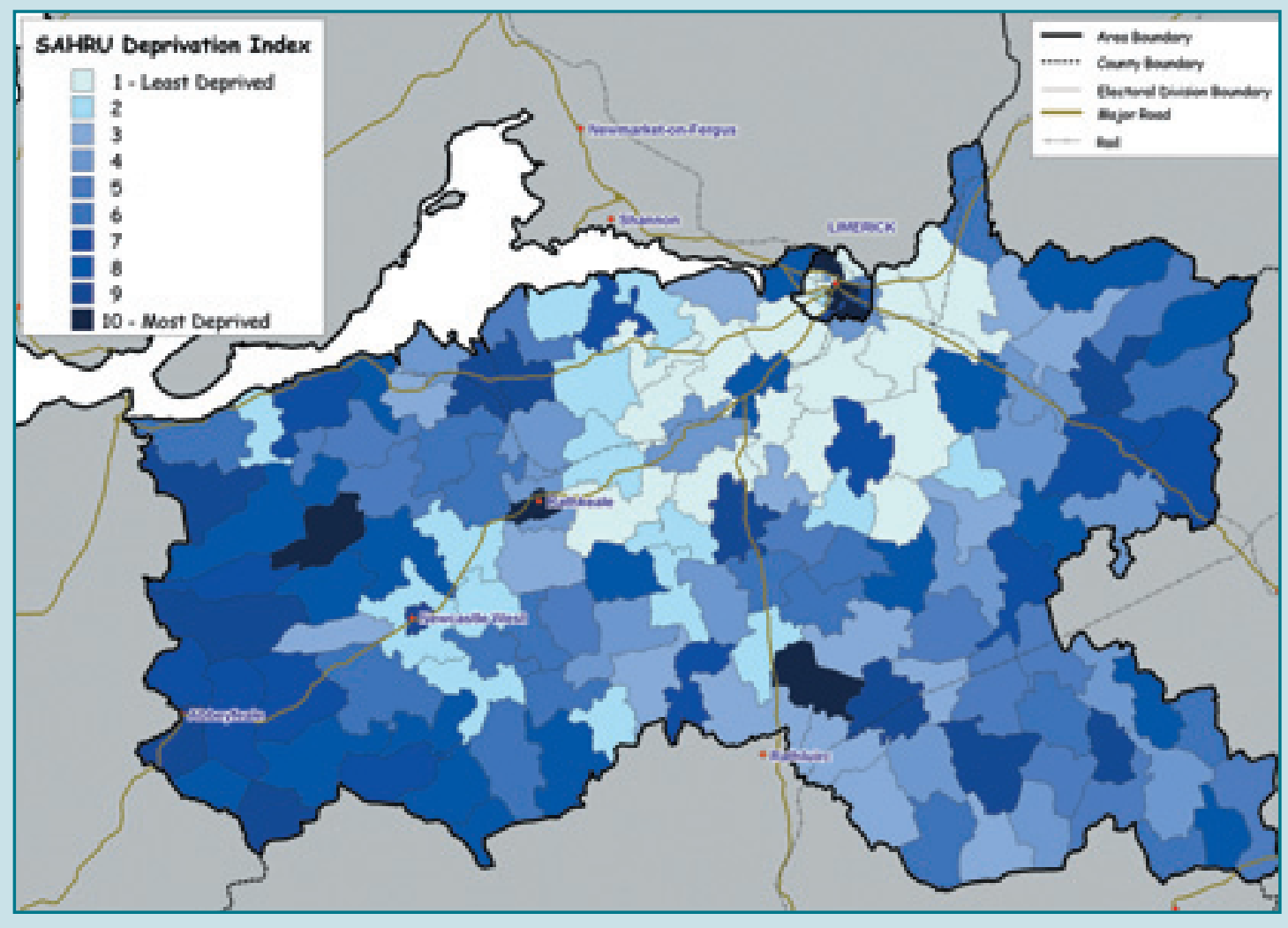


Persons living in Tipperary North Mental Health Catchment Area by level of deprivation

\begin{tabular}{|r|r|r|r|}
\hline \begin{tabular}{l} 
SAHRU $\begin{array}{l}\text { Deprivation } \\
\text { Index (2002) }\end{array}$ \\
\hline 1
\end{tabular} & $\begin{array}{l}\text { No. of Electoral } \\
\text { Divisions }\end{array}$ & $\begin{array}{l}\text { Catchment Area } \\
\text { Population }\end{array}$ & $\begin{array}{l}\text { \% Catchment } \\
\text { Area Population }\end{array}$ \\
\hline 2 & 11 & 8,870 & $14.54 \%$ \\
\hline 3 & 13 & 5,704 & $9.35 \%$ \\
\hline 4 & 14 & 5,474 & $8.97 \%$ \\
\hline 5 & 7 & 3,659 & $6.00 \%$ \\
\hline 6 & 10 & 5,135 & $8.42 \%$ \\
\hline 7 & 7 & 2,731 & $4.48 \%$ \\
\hline 8 & 3 & 1,333 & $2.18 \%$ \\
\hline 9 & 8 & 7,289 & $11.95 \%$ \\
\hline 10 & 7 & 20,815 & $34.12 \%$ \\
\hline Total & 0 & 0 & $0.00 \%$ \\
\hline & 80 & 61,010 & \\
\hline
\end{tabular}

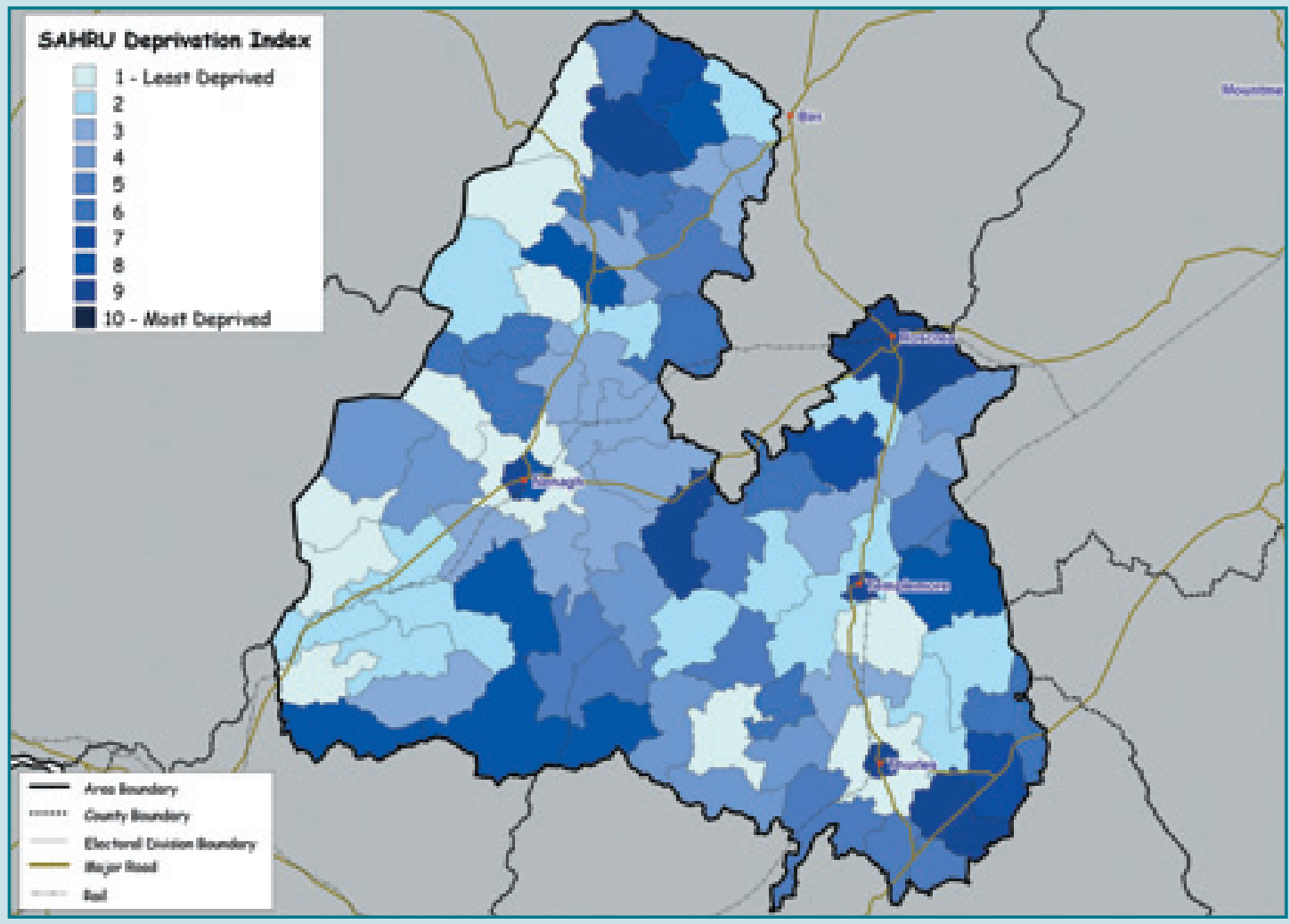


HSE - Midlands Area

Persons living Laois/Offaly Mental Health Catchment Area by level of deprivation

\begin{tabular}{|r|r|r|r|}
\hline \begin{tabular}{l} 
SAHRU $\begin{array}{l}\text { Deprivation } \\
\text { Index (2002) }\end{array}$ \\
\hline 1
\end{tabular} & $\begin{array}{l}\text { No. of Electoral } \\
\text { Divisions }\end{array}$ & $\begin{array}{l}\text { Catchment Area } \\
\text { Population }\end{array}$ & $\begin{array}{l}\text { \% Catchment } \\
\text { Area Population }\end{array}$ \\
\hline 2 & 8 & 3,967 & $3.24 \%$ \\
\hline 3 & 17 & 7,730 & $6.31 \%$ \\
\hline 4 & 18 & 5,517 & $4.51 \%$ \\
\hline 5 & 28 & 9,024 & $7.37 \%$ \\
\hline 6 & 29 & 13,322 & $10.88 \%$ \\
\hline 7 & 22 & 8,928 & $7.29 \%$ \\
\hline 8 & 14 & 8,205 & $6.70 \%$ \\
\hline 9 & 21 & 10,316 & $8.43 \%$ \\
\hline 10 & 19 & 43,469 & $35.50 \%$ \\
\hline Total & 7 & 11,959 & $9.77 \%$ \\
\hline
\end{tabular}

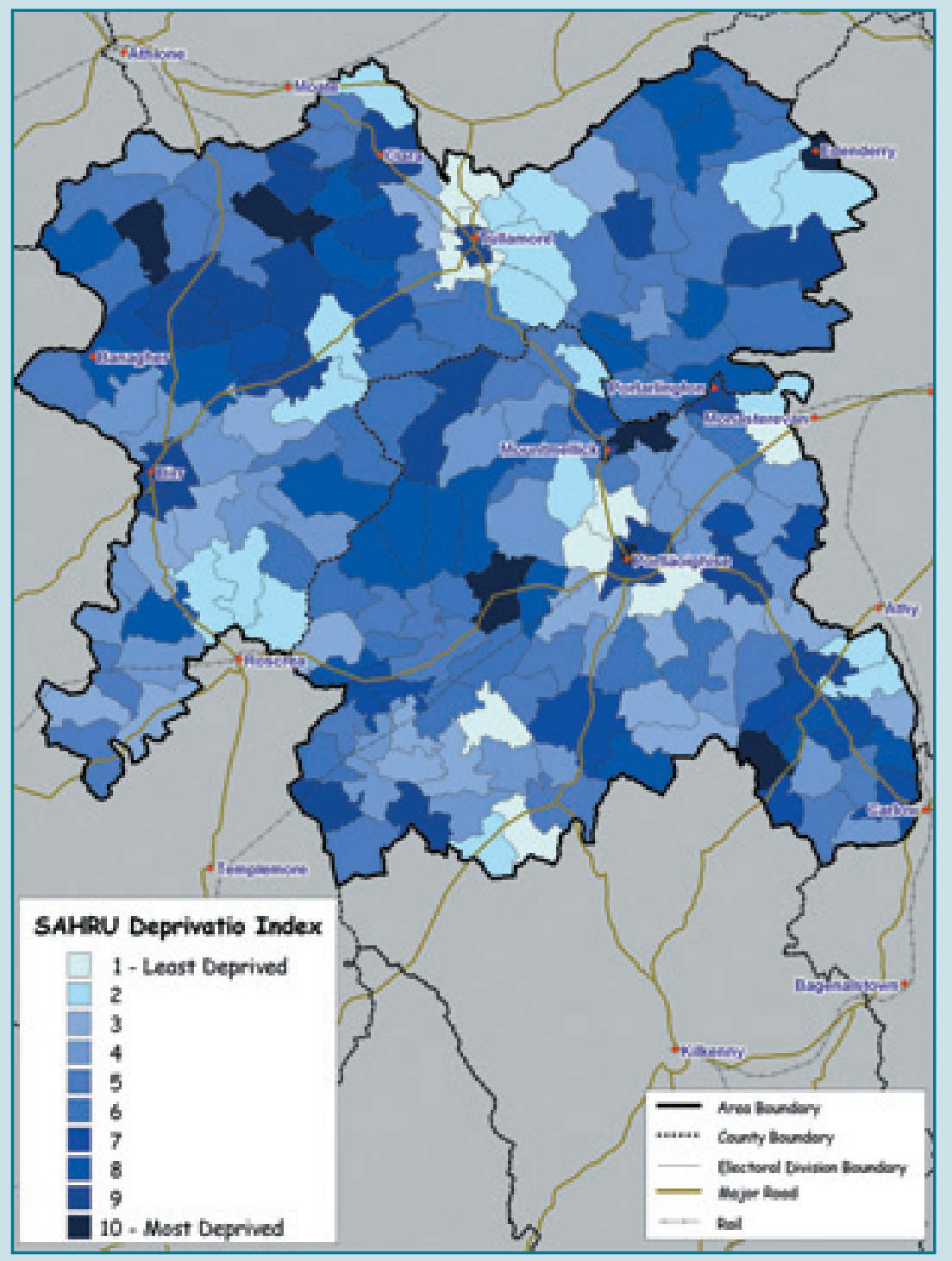


Persons living in Longford/Westmeath Mental Health Catchment Area by level of deprivation

\begin{tabular}{|r|r|r|r|}
\hline \begin{tabular}{l} 
SAHRU $\begin{array}{l}\text { Deprivation } \\
\text { Index (2002) }\end{array}$ \\
\hline 1
\end{tabular} & $\begin{array}{l}\text { No. of Electoral } \\
\text { Divisions }\end{array}$ & $\begin{array}{l}\text { Catchment Area } \\
\text { Population }\end{array}$ & $\begin{array}{l}\text { \% Catchment } \\
\text { Area Population }\end{array}$ \\
\hline 2 & 9 & 5,388 & $5.13 \%$ \\
\hline 3 & 19 & 8,712 & $8.30 \%$ \\
\hline 4 & 17 & 6,051 & $5.76 \%$ \\
\hline 5 & 21 & 14,498 & $13.81 \%$ \\
\hline 6 & 19 & 6,244 & $5.95 \%$ \\
\hline 7 & 17 & 15,583 & $14.84 \%$ \\
\hline 8 & 28 & 12,433 & $11.84 \%$ \\
\hline Total & 16 & 7,697 & $7.33 \%$ \\
\hline 10 & 11 & 13,796 & $13.14 \%$ \\
\hline & 7 & 14,597 & $13.90 \%$ \\
\hline
\end{tabular}

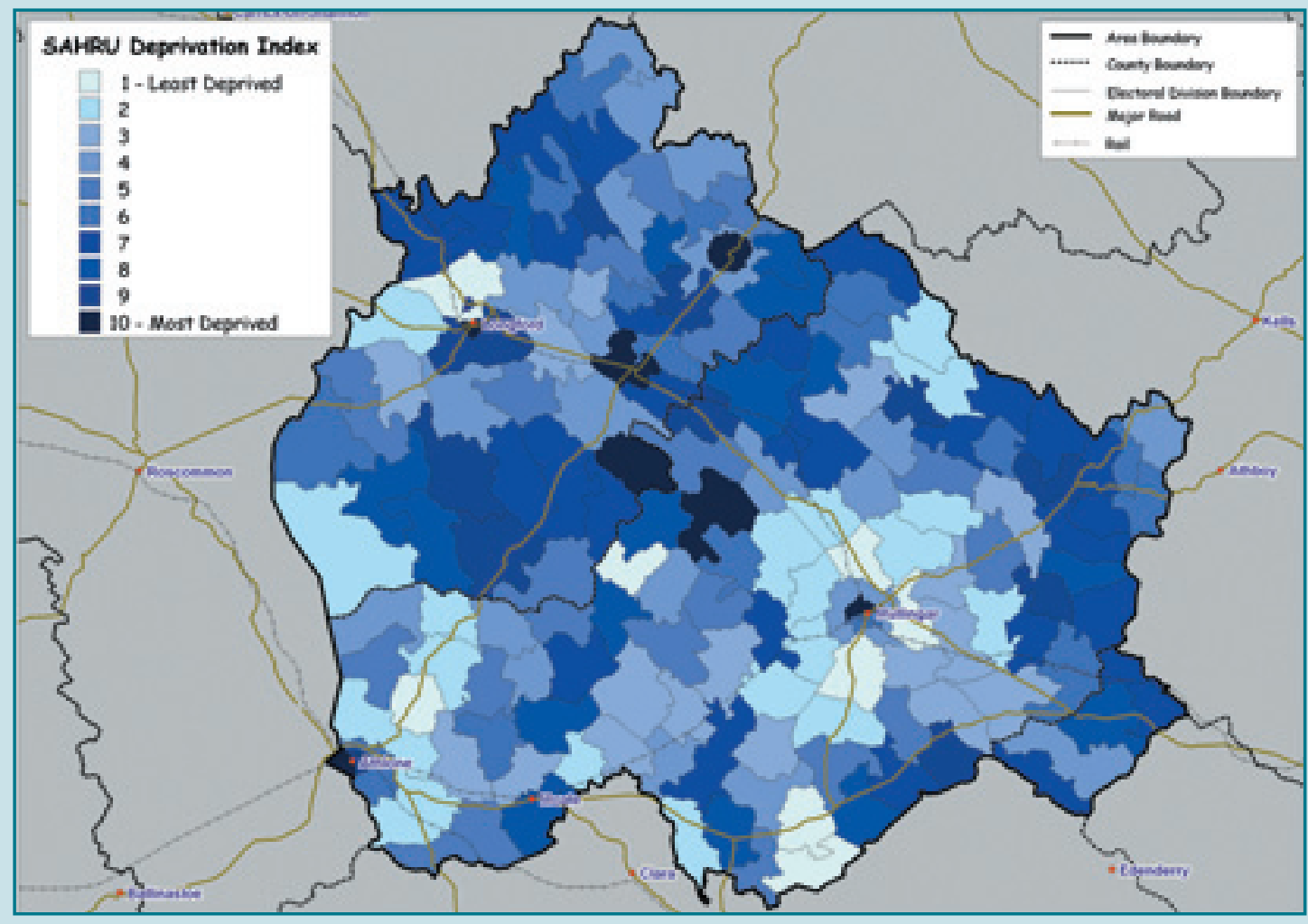


HSE - North Eastern Area

Persons living Cavan/Monaghan Mental Health Catchment Area by level of deprivation

\begin{tabular}{|r|r|r|r|}
\hline $\begin{array}{l}\text { SAHRU } \\
\text { Deprivation } \\
\text { Index (2002) }\end{array}$ & $\begin{array}{l}\text { No. of Electoral } \\
\text { Divisions }\end{array}$ & $\begin{array}{l}\text { Catchment Area } \\
\text { Population }\end{array}$ & $\begin{array}{l}\text { \% Catchment } \\
\text { Area Population }\end{array}$ \\
\hline 1 & 5 & 6,386 & $5.92 \%$ \\
\hline 2 & 12 & 6,008 & $5.57 \%$ \\
\hline 3 & 12 & 5,928 & $5.49 \%$ \\
\hline 4 & 14 & 7,849 & $7.27 \%$ \\
\hline 5 & 19 & 11,925 & $11.05 \%$ \\
\hline 6 & 25 & 12,779 & $11.84 \%$ \\
\hline 7 & 27 & 14,578 & $13.50 \%$ \\
\hline 8 & 19 & 19,770 & $18.31 \%$ \\
\hline 9 & 16 & 15,638 & $14.49 \%$ \\
\hline 10 & 5 & 7,090 & $6.57 \%$ \\
\hline Total & 154 & 107,951 & \\
\hline
\end{tabular}

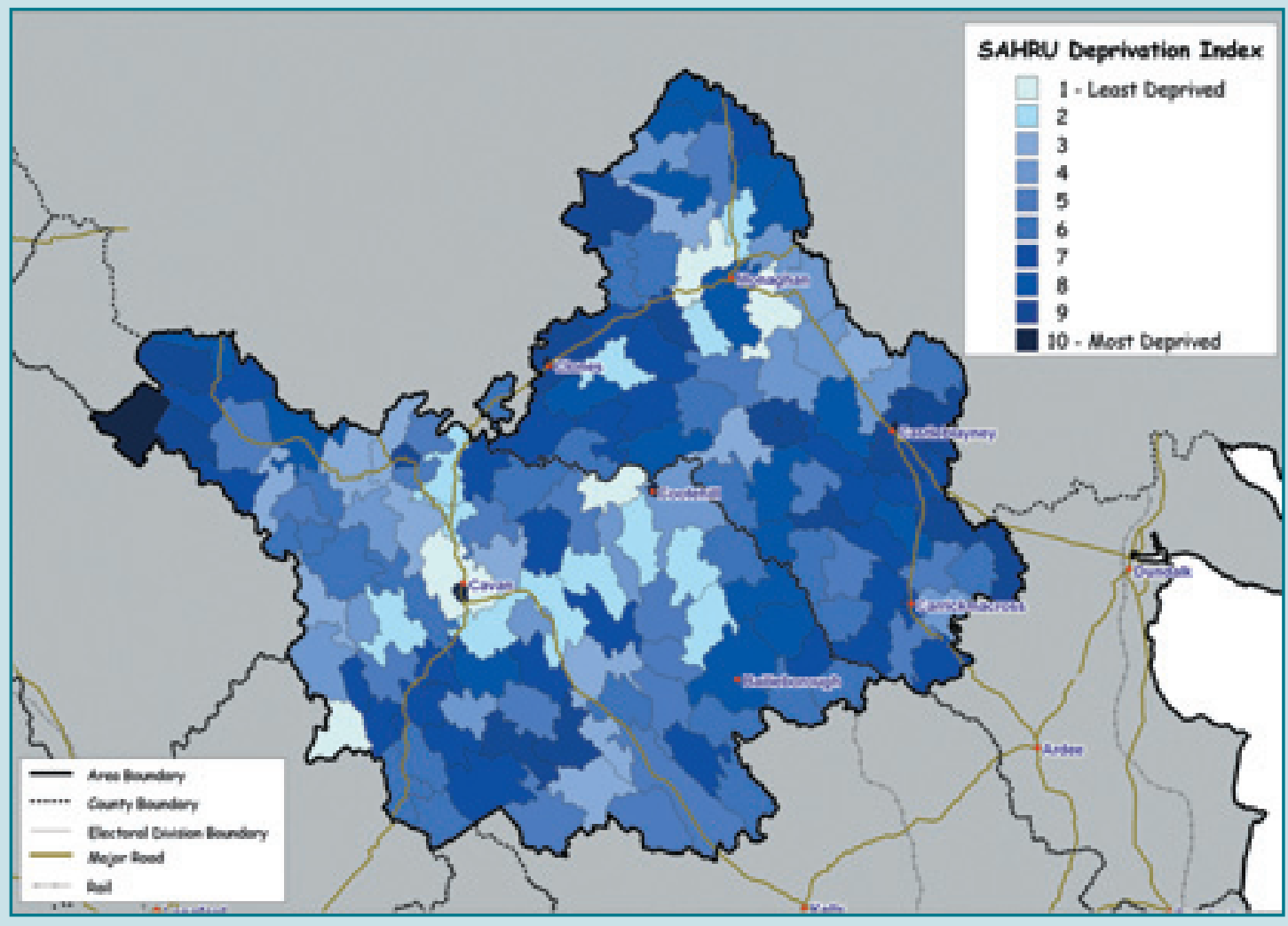


Persons in living in Louth/Meath Mental Health Catchment Area by level of deprivation

\begin{tabular}{|r|r|r|r|}
\hline \begin{tabular}{l} 
SAHRU $\begin{array}{l}\text { Deprivation } \\
\text { Index (2002) }\end{array}$ \\
\hline 1
\end{tabular} & $\begin{array}{l}\text { No. of Electoral } \\
\text { Divisions }\end{array}$ & $\begin{array}{l}\text { Catchment Area } \\
\text { Population }\end{array}$ & $\begin{array}{l}\text { \% Catchment } \\
\text { Area Population }\end{array}$ \\
\hline 2 & 11 & 23,830 & $10.19 \%$ \\
\hline 3 & 16 & 22,298 & $9.54 \%$ \\
\hline 4 & 13 & 21,580 & $9.23 \%$ \\
\hline 5 & 21 & 16,458 & $7.04 \%$ \\
\hline 6 & 10 & 13,066 & $5.59 \%$ \\
\hline 7 & 16 & 36,457 & $15.60 \%$ \\
\hline 8 & 13 & 16,687 & $7.14 \%$ \\
\hline 9 & 13 & 17,205 & $7.36 \%$ \\
\hline 10 & 11 & 23,539 & $10.07 \%$ \\
\hline Total & 7 & 42,633 & $18.24 \%$ \\
\hline
\end{tabular}

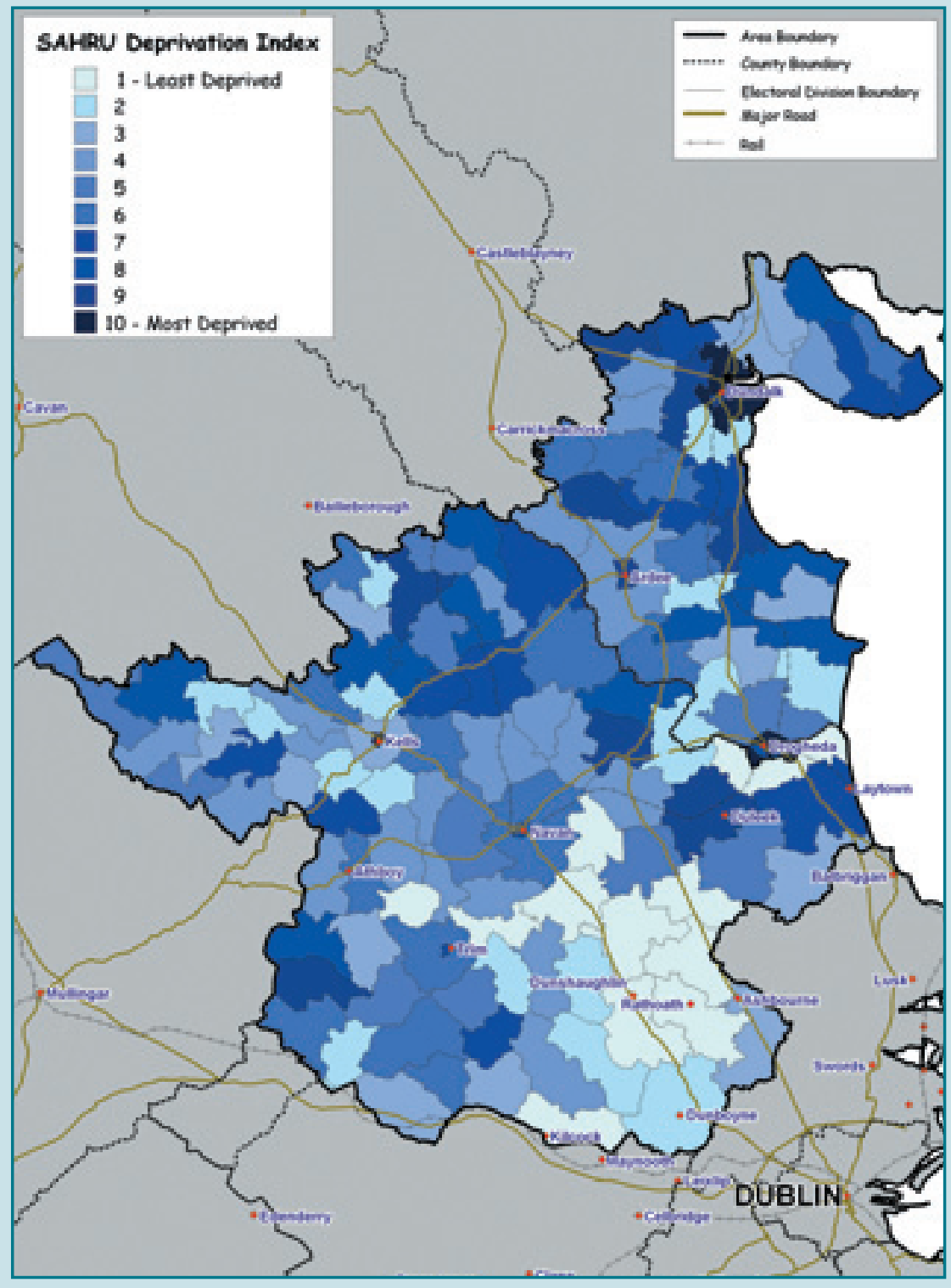


HSE - North Western Area

Persons living in Donegal Mental Health Catchment Area by level of deprivation

\begin{tabular}{|r|r|r|r|}
\hline $\begin{array}{l}\text { SAHRU } \\
\begin{array}{l}\text { Deprivation } \\
\text { Index (2002) }\end{array}\end{array}$ & $\begin{array}{l}\text { No. of Electoral } \\
\text { Divisions }\end{array}$ & $\begin{array}{l}\text { Catchment Area } \\
\text { Population }\end{array}$ & $\begin{array}{l}\text { \% Catchment } \\
\text { Area Population }\end{array}$ \\
\hline 1 & 1 & 2,942 & $2.28 \%$ \\
\hline 2 & 0 & 0 & $0.00 \%$ \\
\hline 3 & 0 & 0 & $0.00 \%$ \\
\hline 4 & 1 & 296 & $0.23 \%$ \\
\hline 5 & 2 & 989 & $0.77 \%$ \\
\hline 6 & 12 & 11,214 & $8.69 \%$ \\
\hline 7 & 4 & 3,162 & $2.45 \%$ \\
\hline 8 & 15 & 18,677 & $14.48 \%$ \\
\hline 9 & 55 & 49,234 & $38.16 \%$ \\
\hline 10 & 49 & 42,494 & $32.94 \%$ \\
\hline Total & 139 & 129,008 & \\
\hline
\end{tabular}

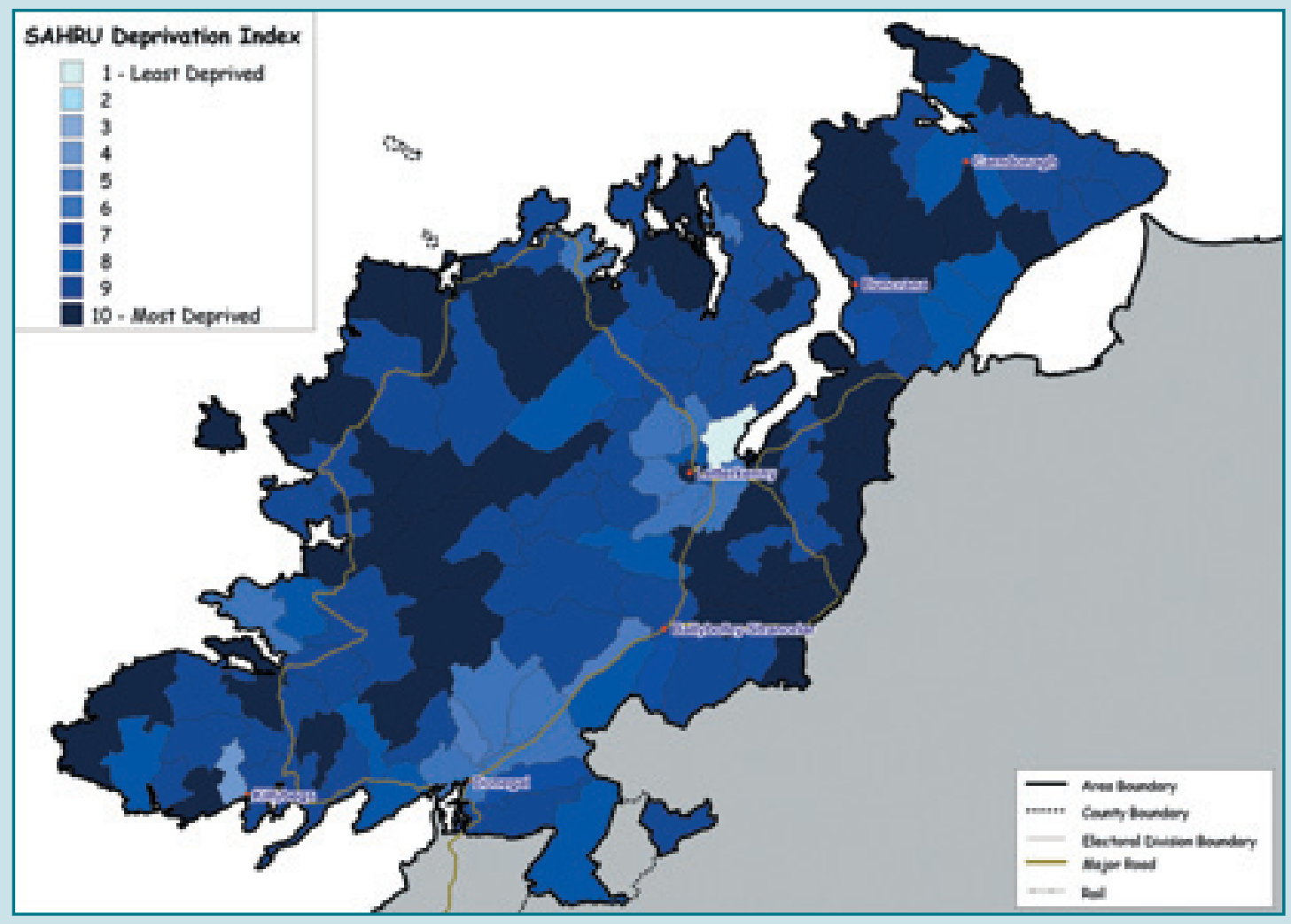


Persons living in Sligo/Leitrim Mental Health Catchment Area by level of deprivation

\begin{tabular}{|r|r|r|r|}
\hline \begin{tabular}{l} 
SAHRU $\begin{array}{l}\text { Deprivation } \\
\text { Index (2002) }\end{array}$ \\
\hline 1
\end{tabular} & $\begin{array}{l}\text { No. of Electoral } \\
\text { Divisions }\end{array}$ & $\begin{array}{l}\text { Catchment Area } \\
\text { Population }\end{array}$ & $\begin{array}{l}\text { \% Catchment } \\
\text { Area Population }\end{array}$ \\
\hline 2 & 11 & 9,459 & $10.09 \%$ \\
\hline 3 & 10 & 7,530 & $8.03 \%$ \\
\hline 4 & 8 & 2,486 & $2.65 \%$ \\
\hline 5 & 18 & 5,922 & $6.32 \%$ \\
\hline 6 & 16 & 8,353 & $8.91 \%$ \\
\hline 7 & 26 & 8,731 & $9.31 \%$ \\
\hline 8 & 26 & 16,378 & $17.47 \%$ \\
\hline 9 & 29 & 11,210 & $11.96 \%$ \\
\hline 10 & 21 & 10,536 & $11.24 \%$ \\
\hline Total & 8 & 13,149 & $14.03 \%$ \\
\hline
\end{tabular}

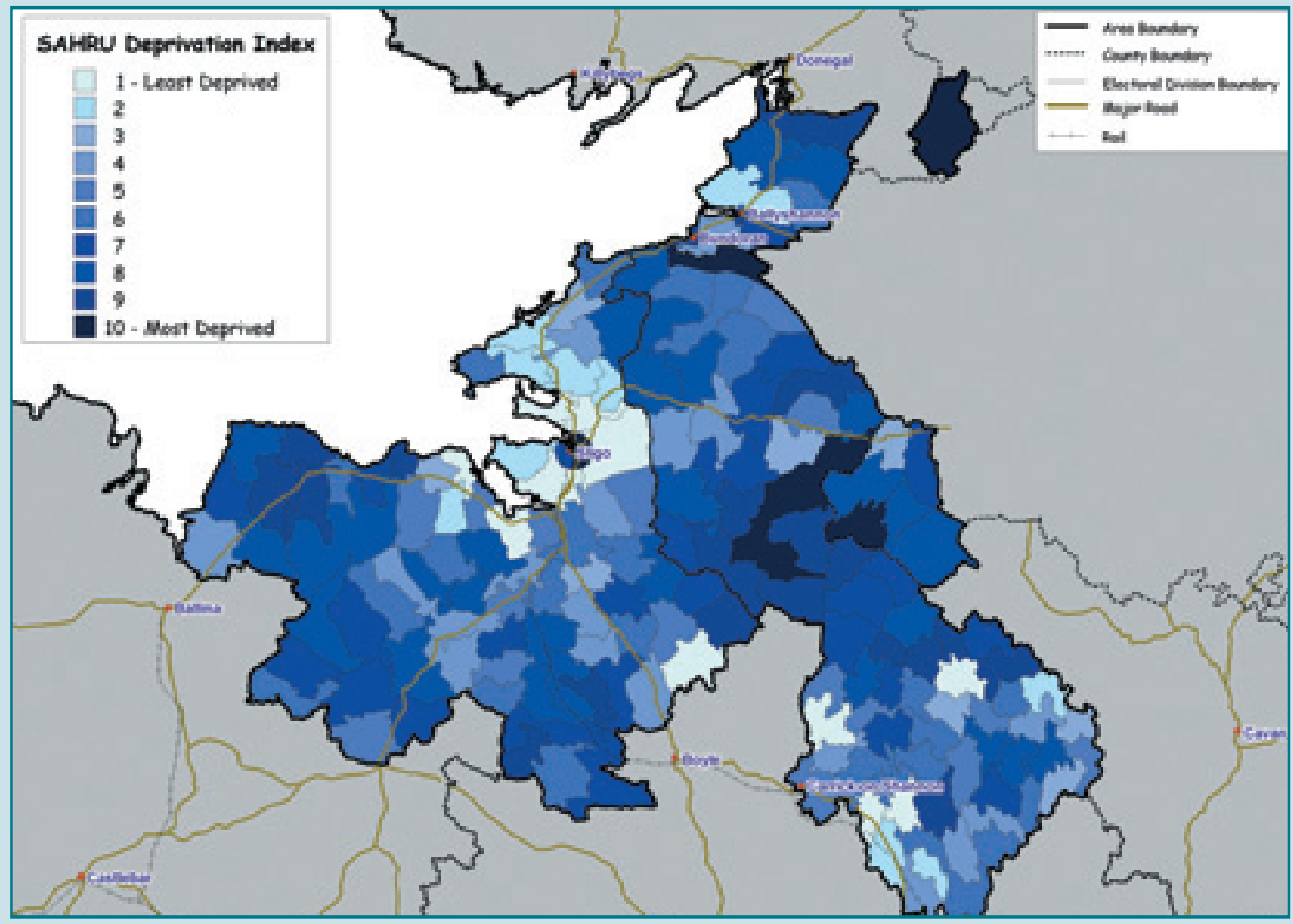


HSE - South Eastern Area

Persons living in Tipperary South Mental Health Catchment Area by level of deprivation

\begin{tabular}{|r|r|r|r|}
\hline \begin{tabular}{l} 
SAHRU $\begin{array}{l}\text { Deprivation } \\
\text { Index (2002) }\end{array}$ \\
\hline 1
\end{tabular} & $\begin{array}{l}\text { No. of Electoral } \\
\text { Divisions }\end{array}$ & $\begin{array}{l}\text { Catchment Area } \\
\text { Population }\end{array}$ & $\begin{array}{l}\text { \% Catchment } \\
\text { Area Population }\end{array}$ \\
\hline 2 & 7 & 3,813 & $4.82 \%$ \\
\hline 3 & 9 & 7,342 & $9.28 \%$ \\
\hline 4 & 7 & 3,348 & $4.23 \%$ \\
\hline 5 & 13 & 5,580 & $7.05 \%$ \\
\hline 6 & 11 & 5,900 & $7.46 \%$ \\
\hline 7 & 13 & 5,494 & $6.94 \%$ \\
\hline 8 & 10 & 9,279 & $11.73 \%$ \\
\hline 9 & 9 & 9,209 & $11.64 \%$ \\
\hline 10 & 9 & 12,012 & $15.18 \%$ \\
\hline Total & 8 & 17,144 & $21.67 \%$ \\
\hline
\end{tabular}

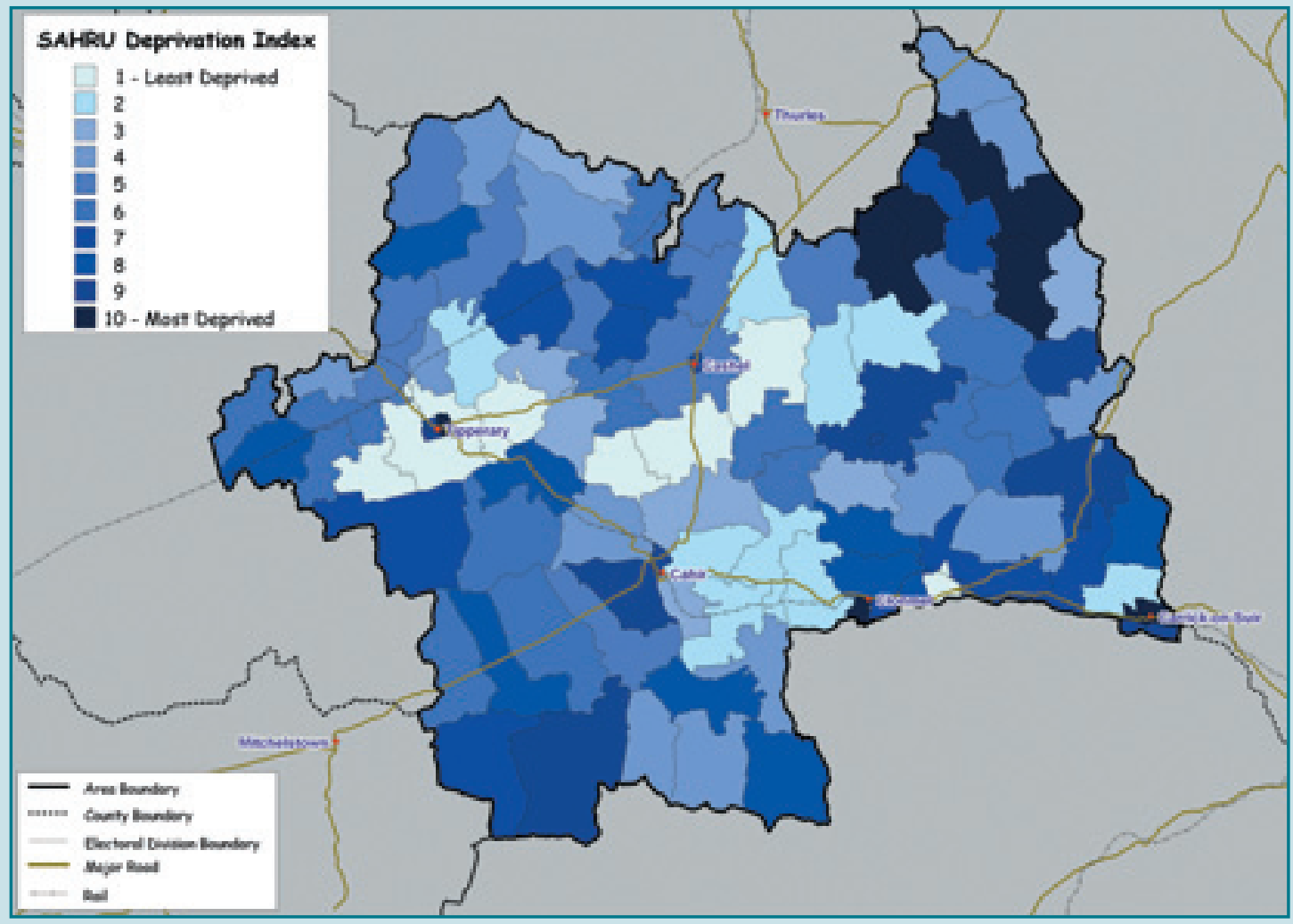


Persons living in Waterford Mental health Catchment Area by level of deprivation

\begin{tabular}{|r|r|r|r|}
\hline \begin{tabular}{l} 
SAHRU $\begin{array}{l}\text { Deprivation } \\
\text { Index (2002) }\end{array}$ \\
\hline 1
\end{tabular} & $\begin{array}{l}\text { No. of Electoral } \\
\text { Divisions }\end{array}$ & $\begin{array}{l}\text { Catchment Area } \\
\text { Population }\end{array}$ & $\begin{array}{l}\text { \% Catchment } \\
\text { Area Population }\end{array}$ \\
\hline 2 & 12 & 15,204 & $14.97 \%$ \\
\hline 3 & 7 & 3,729 & $3.67 \%$ \\
\hline 4 & 13 & 6,221 & $6.13 \%$ \\
\hline 5 & 10 & 3,591 & $3.54 \%$ \\
\hline 6 & 15 & 8,687 & $8.55 \%$ \\
\hline 7 & 11 & 10,139 & $9.98 \%$ \\
\hline 8 & 13 & 12,049 & $11.87 \%$ \\
\hline 9 & 10 & 4,780 & $4.71 \%$ \\
\hline 10 & 10 & 11,406 & $11.23 \%$ \\
\hline Total & 21 & 25,740 & $25.35 \%$ \\
\hline & 122 & $101,546 \%$ & \\
\hline
\end{tabular}

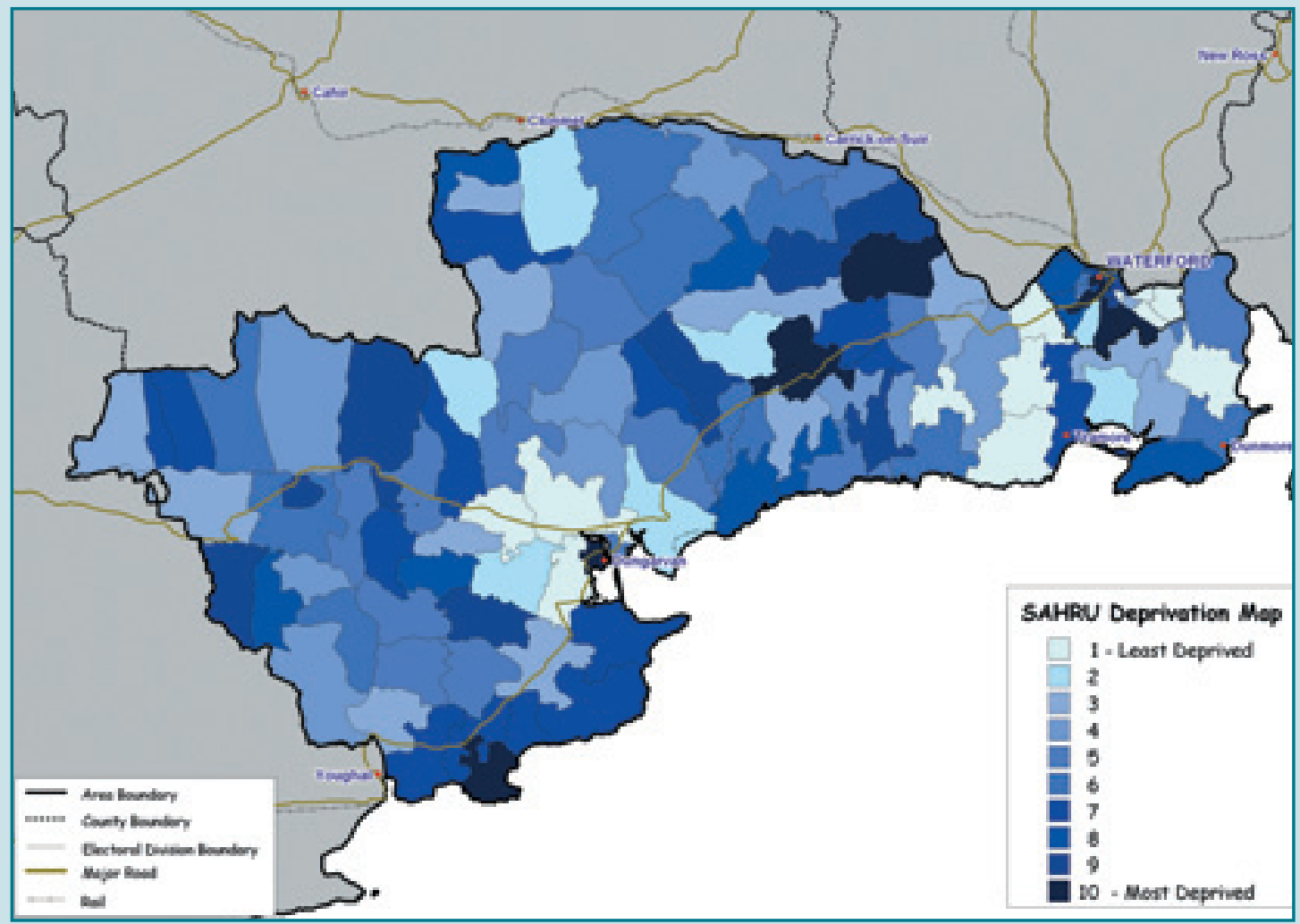

* The table gives the population of Waterford county (101,546 Census 2002). The population of Waterford Mental Health Catchmant Area is 116,588. 15,042 persons from South Kilkenny are in the Waterford Mental Health Catchment Area. 
Persons living in Wexford Mental Health Catchment Area by level of deprivation

\begin{tabular}{|r|r|r|r|}
\hline $\begin{array}{l}\text { SAHRU } \\
\begin{array}{l}\text { Deprivation } \\
\text { Index (2002) }\end{array}\end{array}$ & $\begin{array}{l}\text { No. of Electoral } \\
\text { Divisions }\end{array}$ & $\begin{array}{l}\text { Catchment Area } \\
\text { Population }\end{array}$ & $\begin{array}{l}\text { \% Catchment } \\
\text { Area Population }\end{array}$ \\
\hline 1 & 3 & 2,239 & $1.92 \%$ \\
\hline 2 & 6 & 3,000 & $2.57 \%$ \\
\hline 3 & 13 & 8,865 & $7.60 \%$ \\
\hline 4 & 17 & 9,294 & $7.97 \%$ \\
\hline 5 & 22 & 11,574 & $9.93 \%$ \\
\hline 6 & 10 & 7,311 & $6.27 \%$ \\
\hline 7 & 20 & 15,130 & $12.98 \%$ \\
\hline 8 & 14 & 23,734 & $20.36 \%$ \\
\hline 9 & 13 & 19,439 & $16.67 \%$ \\
\hline 10 & 6 & 16,010 & $13.73 \%$ \\
\hline Total & 124 & 116,596 & \\
\hline
\end{tabular}

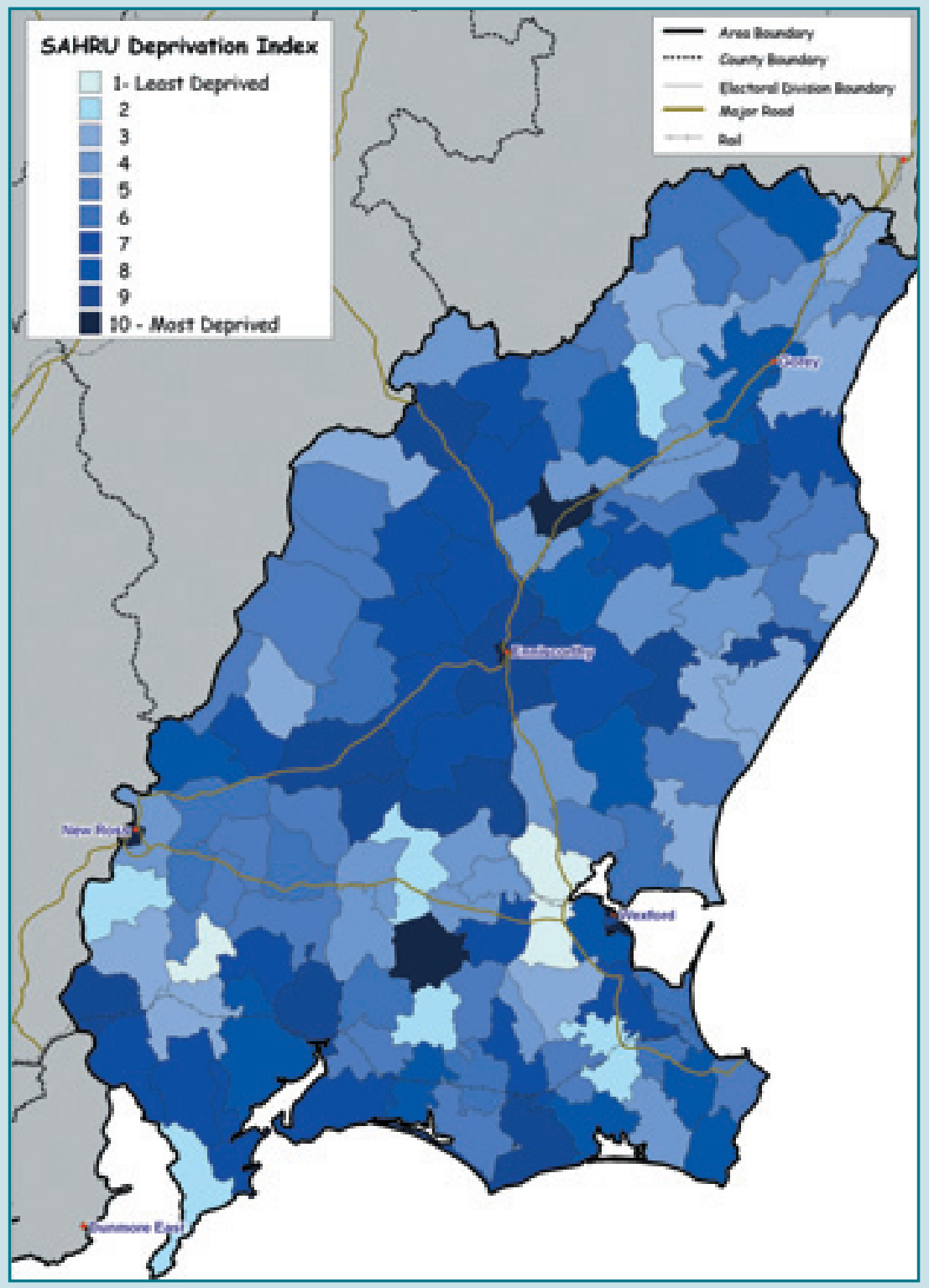


Persons living in Carlow/Kilkenny Mental Health Catchment Area by level of deprivation

\begin{tabular}{|r|r|r|r|}
\hline \begin{tabular}{l} 
SAHRU $\begin{array}{l}\text { Deprivation } \\
\text { Index (2002) }\end{array}$ \\
\hline 1
\end{tabular} & $\begin{array}{l}\text { No. of Electoral } \\
\text { Divisions }\end{array}$ & $\begin{array}{l}\text { Catchment Area } \\
\text { Population }\end{array}$ & $\begin{array}{l}\text { \% Catchment } \\
\text { Area Population }\end{array}$ \\
\hline 2 & 17 & 9,064 & $7.17 \%$ \\
\hline 3 & 27 & 9,225 & $7.30 \%$ \\
\hline 4 & 22 & 8,374 & $6.63 \%$ \\
\hline 5 & 17 & 6,308 & $4.99 \%$ \\
\hline 6 & 17 & 21,485 & $17.00 \%$ \\
\hline 7 & 20 & 18,117 & $14.34 \%$ \\
\hline 8 & 11 & 6,088 & $4.82 \%$ \\
\hline 9 & 13 & 11,800 & $9.34 \%$ \\
\hline 10 & 15 & 16,560 & $13.11 \%$ \\
\hline Total & 8 & 19,332 & $15.30 \%$ \\
\hline
\end{tabular}

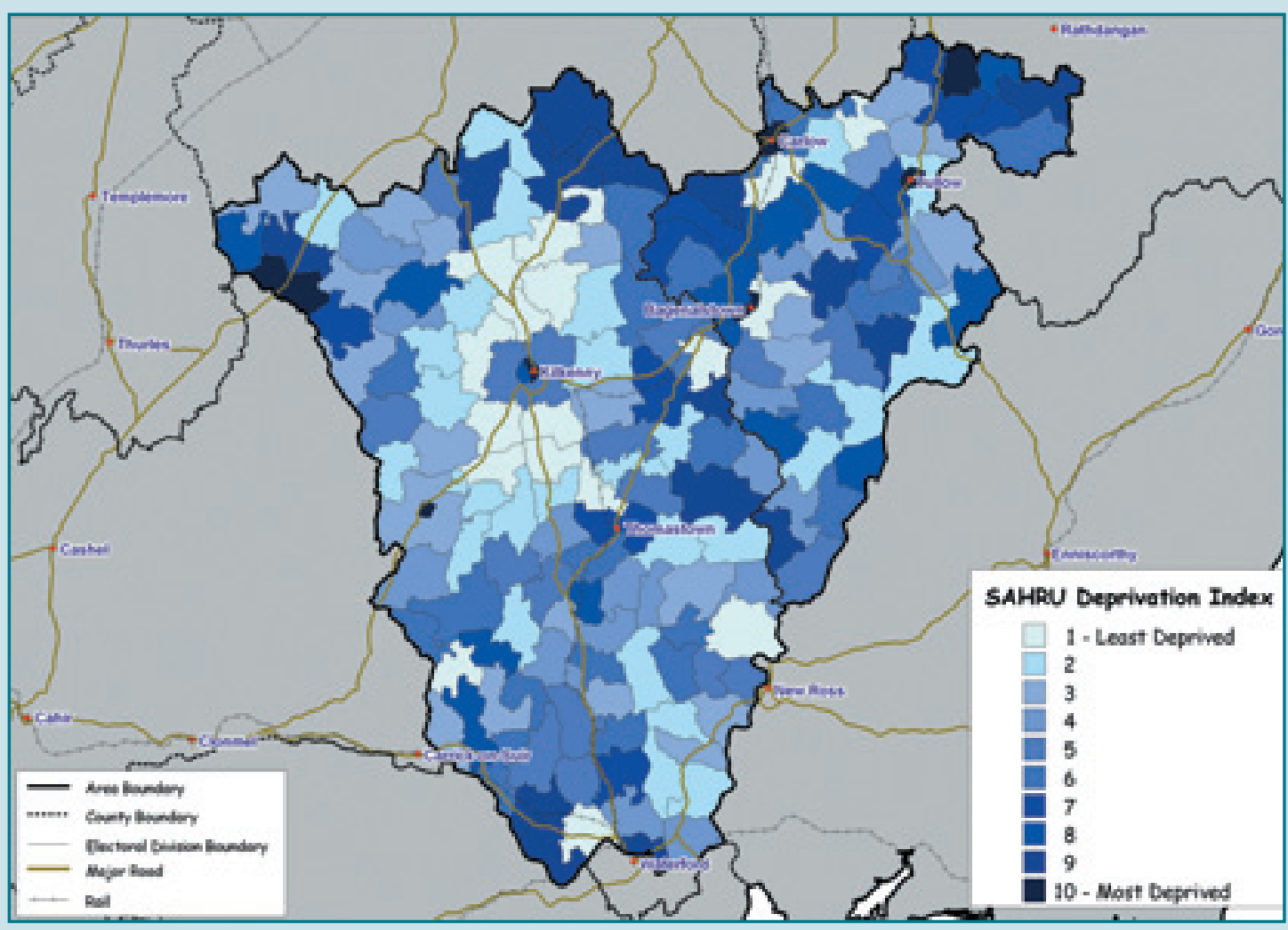

* The table gives the population of the counties of Carlow and Kilkenny (126,353, census 2002). The population of Carlow/Kilkenny Mental Health Catchment Area is 111,312. 15,042 persons from South Kilkenny are in the Waterford Mental Health Catchment Area. 
HSE - Southern Area

Persons living in Kerry Mental Health Catchment Area by level of deprivation

\begin{tabular}{|r|r|r|r|}
\hline $\begin{array}{l}\text { SAHRU } \\
\text { Deprivation } \\
\text { Index (2002) }\end{array}$ & $\begin{array}{l}\text { No. of Electoral } \\
\text { Divisions }\end{array}$ & $\begin{array}{l}\text { Catchment Area } \\
\text { Population }\end{array}$ & $\begin{array}{l}\text { \% Catchment } \\
\text { Area Population }\end{array}$ \\
\hline 1 & 8 & 4,125 & $3.11 \%$ \\
\hline 2 & 7 & 3,115 & $2.35 \%$ \\
\hline 3 & 8 & 4,980 & $3.76 \%$ \\
\hline 4 & 17 & 9,091 & $6.86 \%$ \\
\hline 5 & 20 & 20,461 & $15.44 \%$ \\
\hline 6 & 27 & 11,719 & $8.84 \%$ \\
\hline 7 & 24 & 12,362 & $9.33 \%$ \\
\hline 8 & 35 & 45,911 & $34.64 \%$ \\
\hline 9 & 13 & 10,712 & $8.08 \%$ \\
\hline 10 & 7 & 10,051 & $7.58 \%$ \\
\hline & 166 & 132,527 & \\
\hline
\end{tabular}

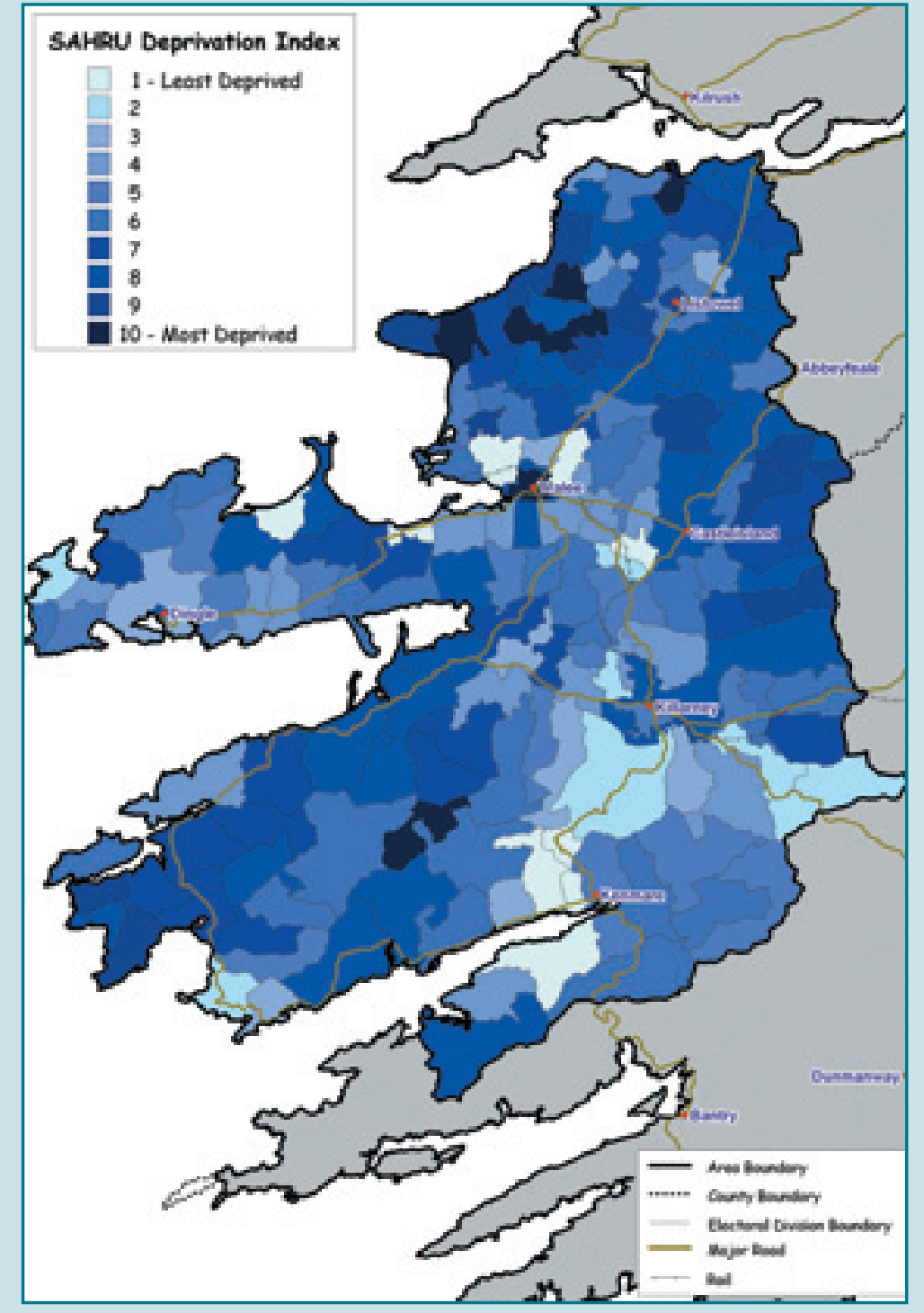


Persons living in North Cork Mental Health Catchment Area by level of deprivation

\begin{tabular}{|r|r|r|r|}
\hline $\begin{array}{l}\text { SAHRU } \\
\text { Deprivation } \\
\text { Index (2002) }\end{array}$ & $\begin{array}{l}\text { No. of Electoral } \\
\text { Divisions }\end{array}$ & $\begin{array}{l}\text { Catchment Area } \\
\text { Population }\end{array}$ & $\begin{array}{l}\text { \% Catchment } \\
\text { Area Population }\end{array}$ \\
\hline 1 & 8 & 3,548 & $4.83 \%$ \\
\hline 2 & 12 & 4,924 & $6.70 \%$ \\
\hline 3 & 15 & 8,178 & $11.12 \%$ \\
\hline 4 & 17 & 8,115 & $11.04 \%$ \\
\hline 5 & 15 & 8,252 & $11.23 \%$ \\
\hline 6 & 10 & 7,251 & $9.86 \%$ \\
\hline 7 & 13 & 9,130 & $12.42 \%$ \\
\hline 8 & 10 & 12,675 & $17.24 \%$ \\
\hline Total & 6 & 11,438 & $15.56 \%$ \\
\hline 10 & 0 & 0 & $0.00 \%$ \\
\hline
\end{tabular}

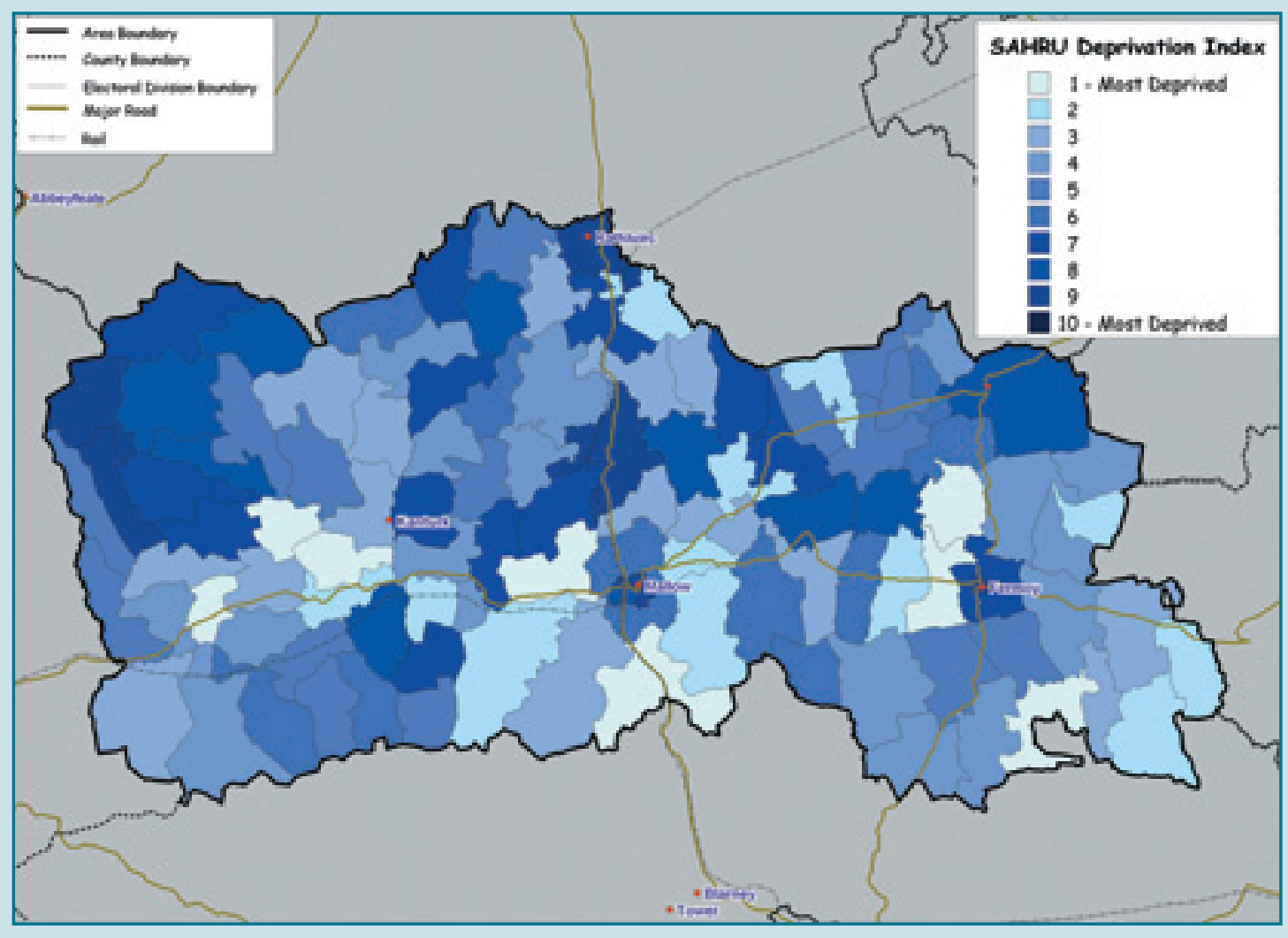


Persons living in North Lee Mental Health Catchment Area by level of deprivation

\begin{tabular}{|r|r|r|r|}
\hline $\begin{array}{l}\text { SAHRU } \\
\begin{array}{l}\text { Deprivation } \\
\text { Index (2002) }\end{array}\end{array}$ & $\begin{array}{l}\text { No. of Electoral } \\
\text { Divisions }\end{array}$ & $\begin{array}{l}\text { Catchment Area } \\
\text { Population }\end{array}$ & $\begin{array}{l}\text { \% Catchment } \\
\text { Area Population }\end{array}$ \\
\hline 1 & 11 & 13,774 & $8.83 \%$ \\
\hline 2 & 10 & 6,891 & $4.42 \%$ \\
\hline 3 & 15 & 17,997 & $11.53 \%$ \\
\hline 4 & 18 & 17,345 & $11.12 \%$ \\
\hline 5 & 8 & 13,291 & $8.52 \%$ \\
\hline 6 & 2 & 6,751 & $4.33 \%$ \\
\hline 7 & 8 & 14,166 & $9.08 \%$ \\
\hline 8 & 5 & 9,079 & $5.82 \%$ \\
\hline 9 & 4 & 12,579 & $8.06 \%$ \\
\hline 10 & 25 & 44,163 & $28.30 \%$ \\
\hline Total & 106 & 156,036 & \\
\hline
\end{tabular}

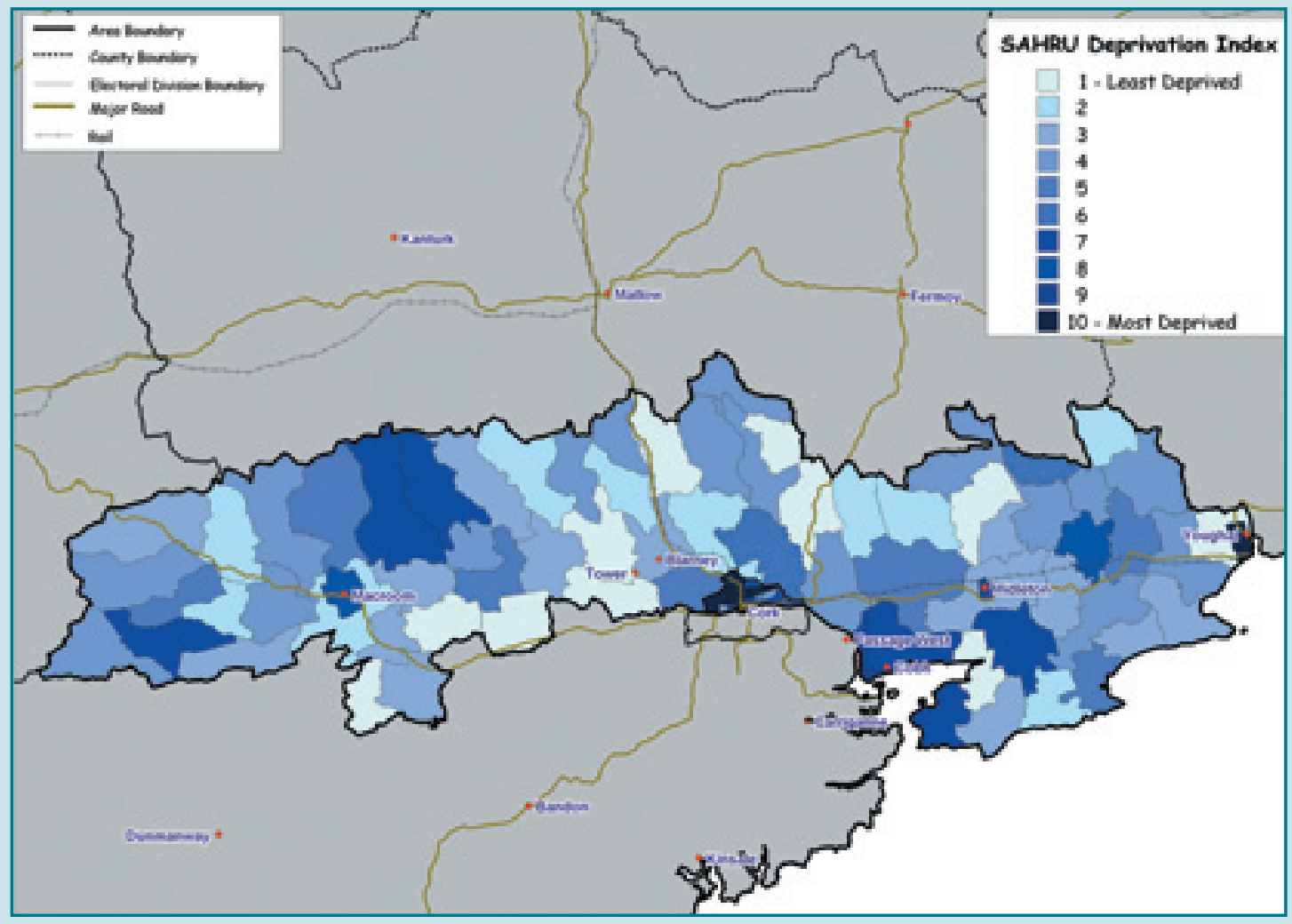


Persons living in South Lee Mental Health Catchment Area by level of deprivation

\begin{tabular}{|r|r|r|r|}
\hline $\begin{array}{l}\text { SAHRU } \\
\begin{array}{l}\text { Deprivation } \\
\text { Index (2002) }\end{array}\end{array}$ & $\begin{array}{l}\text { No. of Electoral } \\
\text { Divisions }\end{array}$ & $\begin{array}{l}\text { Catchment Area } \\
\text { Population }\end{array}$ & $\begin{array}{l}\text { \% Catchment } \\
\text { Area Population }\end{array}$ \\
\hline 1 & 31 & 59,193 & $35.34 \%$ \\
\hline 2 & 12 & 25,606 & $15.29 \%$ \\
\hline 3 & 7 & 20,801 & $12.42 \%$ \\
\hline 4 & 7 & 4,444 & $2.65 \%$ \\
\hline 5 & 6 & 10,481 & $6.26 \%$ \\
\hline 6 & 3 & 1,138 & $0.68 \%$ \\
\hline 7 & 3 & 2,996 & $1.79 \%$ \\
\hline 8 & 4 & 12,862 & $7.68 \%$ \\
\hline 9 & 10 & 16,036 & $9.57 \%$ \\
\hline 10 & 9 & 13,922 & $8.31 \%$ \\
\hline Total & 92 & 167,479 & \\
\hline
\end{tabular}

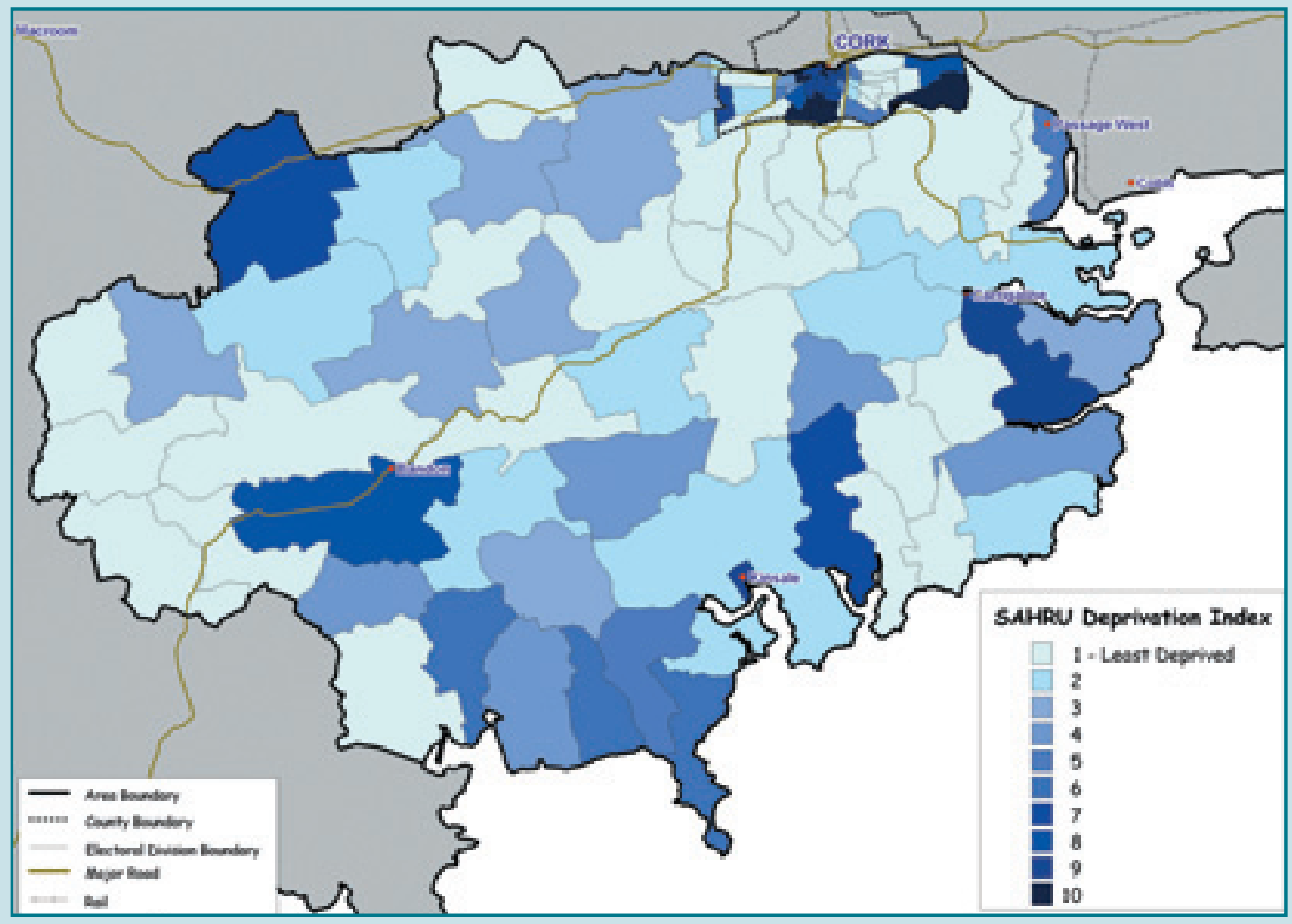


Persons living in West Cork Mental Health Catchment Area by level of deprivation

\begin{tabular}{|r|r|r|r|}
\hline $\begin{array}{l}\text { SAHRU } \\
\begin{array}{l}\text { Deprivation } \\
\text { Index (2002) }\end{array}\end{array}$ & $\begin{array}{l}\text { No. of Electoral } \\
\text { Divisions }\end{array}$ & $\begin{array}{l}\text { Catchment Area } \\
\text { Population }\end{array}$ & $\begin{array}{l}\text { \% Catchment } \\
\text { Area Population }\end{array}$ \\
\hline 1 & 21 & 9,766 & $19.22 \%$ \\
\hline 2 & 17 & 7,761 & $15.28 \%$ \\
\hline 3 & 16 & 6,766 & $13.32 \%$ \\
\hline 4 & 11 & 4,268 & $8.40 \%$ \\
\hline 5 & 9 & 4,566 & $8.99 \%$ \\
\hline 6 & 8 & 3,777 & $7.43 \%$ \\
\hline 7 & 6 & 3,202 & $6.30 \%$ \\
\hline 8 & 5 & 10,267 & $20.21 \%$ \\
\hline 9 & 1 & 430 & $0.85 \%$ \\
\hline 10 & 0 & 0 & $0.00 \%$ \\
\hline Total & 94 & 50,803 & \\
\hline & & &
\end{tabular}

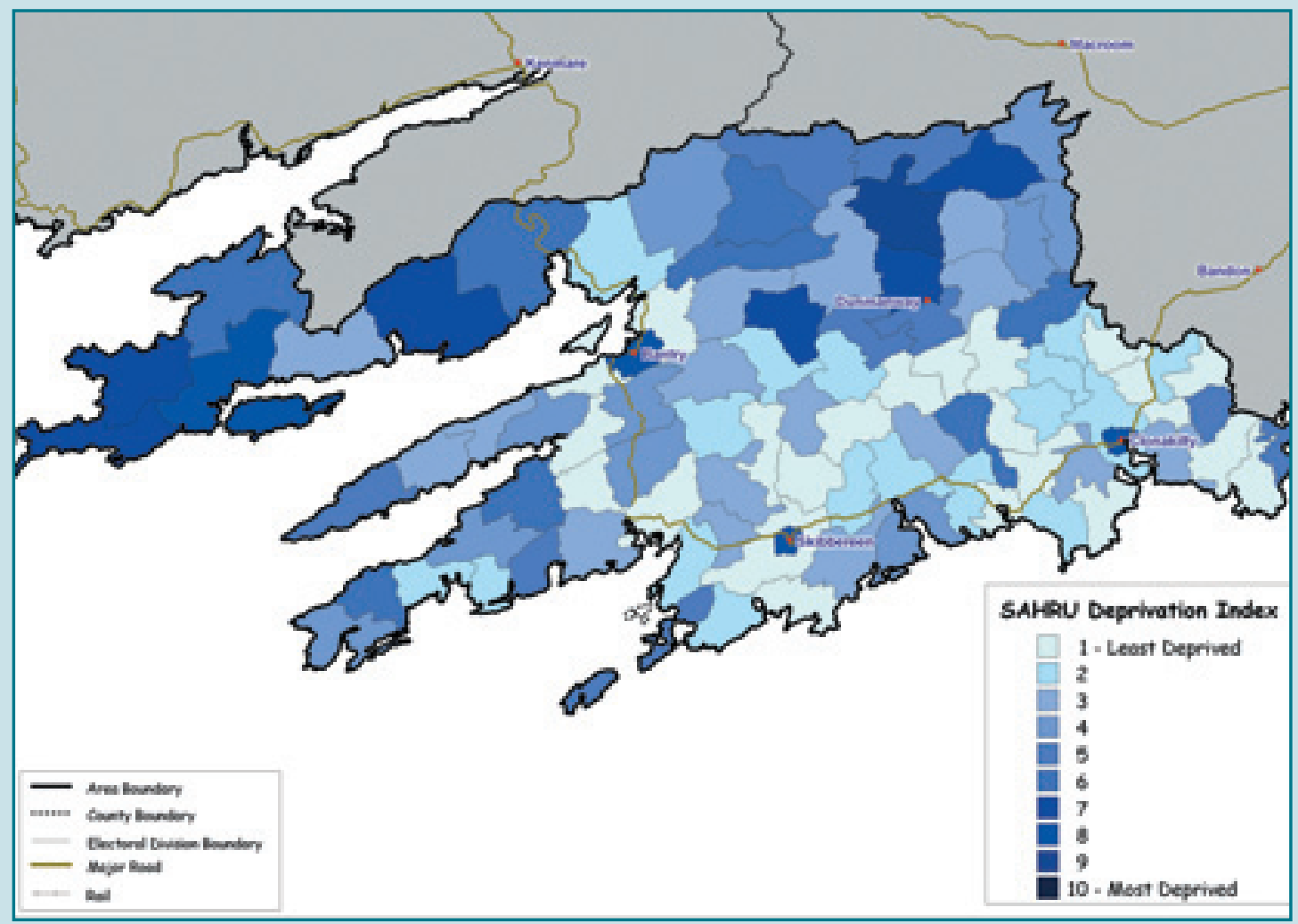


HSE - Western Area

Persons living in East Galway Mental Health Catchment Area by level of deprivation

\begin{tabular}{|r|r|r|r|}
\hline $\begin{array}{l}\text { SAHRU } \\
\begin{array}{l}\text { Deprivation } \\
\text { Index (2002) }\end{array}\end{array}$ & $\begin{array}{l}\text { No. of Electoral } \\
\text { Divisions }\end{array}$ & $\begin{array}{l}\text { latchment Area } \\
\text { Population }\end{array}$ & $\begin{array}{l}\text { \% Catchment } \\
\text { Area Population }\end{array}$ \\
\hline 1 & 9 & 3,982 & $4.03 \%$ \\
\hline 2 & 31 & 18,083 & $18.29 \%$ \\
\hline 3 & 26 & 16,471 & $16.66 \%$ \\
\hline 4 & 17 & 7,264 & $7.35 \%$ \\
\hline 5 & 21 & 9,035 & $9.14 \%$ \\
\hline 6 & 23 & 11,797 & $11.93 \%$ \\
\hline 7 & 14 & 9,266 & $9.37 \%$ \\
\hline 8 & 14 & 8,834 & $8.93 \%$ \\
\hline 9 & 6 & 14,034 & $14.19 \%$ \\
\hline 10 & 1 & 129 & $0.13 \%$ \\
\hline Total & 162 & 98,895 & \\
\hline
\end{tabular}

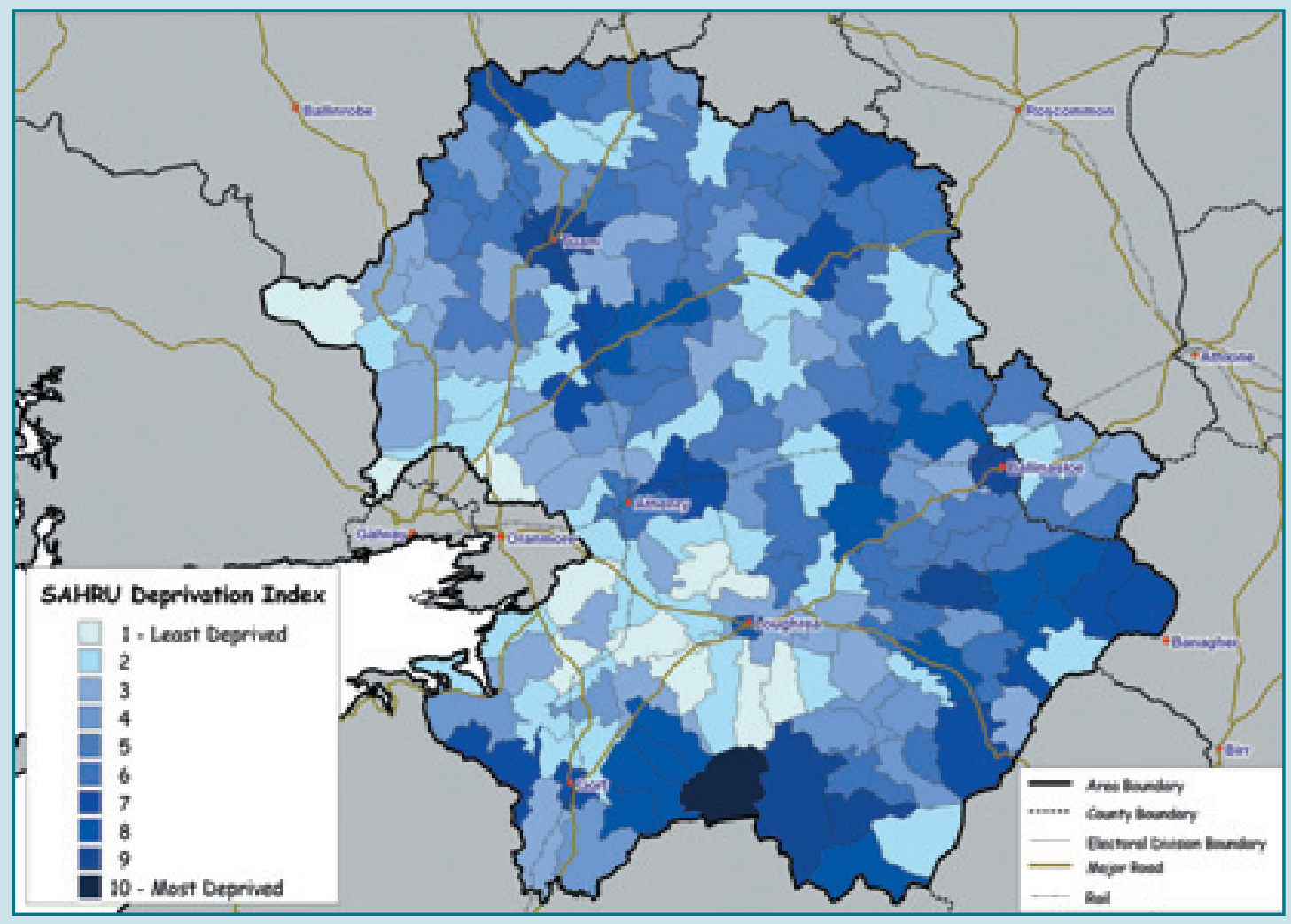


Persons living in West Galway Mental Health Catchment Area by level of deprivation

\begin{tabular}{|r|r|r|r|}
\hline $\begin{array}{l}\text { SAHRU } \\
\begin{array}{l}\text { Deprivation } \\
\text { Index (2002) }\end{array}\end{array}$ & $\begin{array}{l}\text { No. of Electoral } \\
\text { Divisions }\end{array}$ & $\begin{array}{l}\text { Catchment Area } \\
\text { Population }\end{array}$ & $\begin{array}{l}\text { \% Catchment } \\
\text { Area Population }\end{array}$ \\
\hline 1 & 11 & 26,635 & $24.22 \%$ \\
\hline 2 & 2 & 2,639 & $2.40 \%$ \\
\hline 3 & 4 & 6,133 & $5.58 \%$ \\
\hline 4 & 3 & 2,603 & $2.37 \%$ \\
\hline 5 & 3 & 6,635 & $6.03 \%$ \\
\hline 6 & 6 & 6,162 & $5.60 \%$ \\
\hline 7 & 4 & 2,150 & $1.96 \%$ \\
\hline 8 & 7 & 12,551 & $11.42 \%$ \\
\hline 9 & 12 & 19,174 & $17.44 \%$ \\
\hline 10 & 20 & 25,267 & $22.98 \%$ \\
\hline Total & 72 & 109,949 & \\
\hline
\end{tabular}

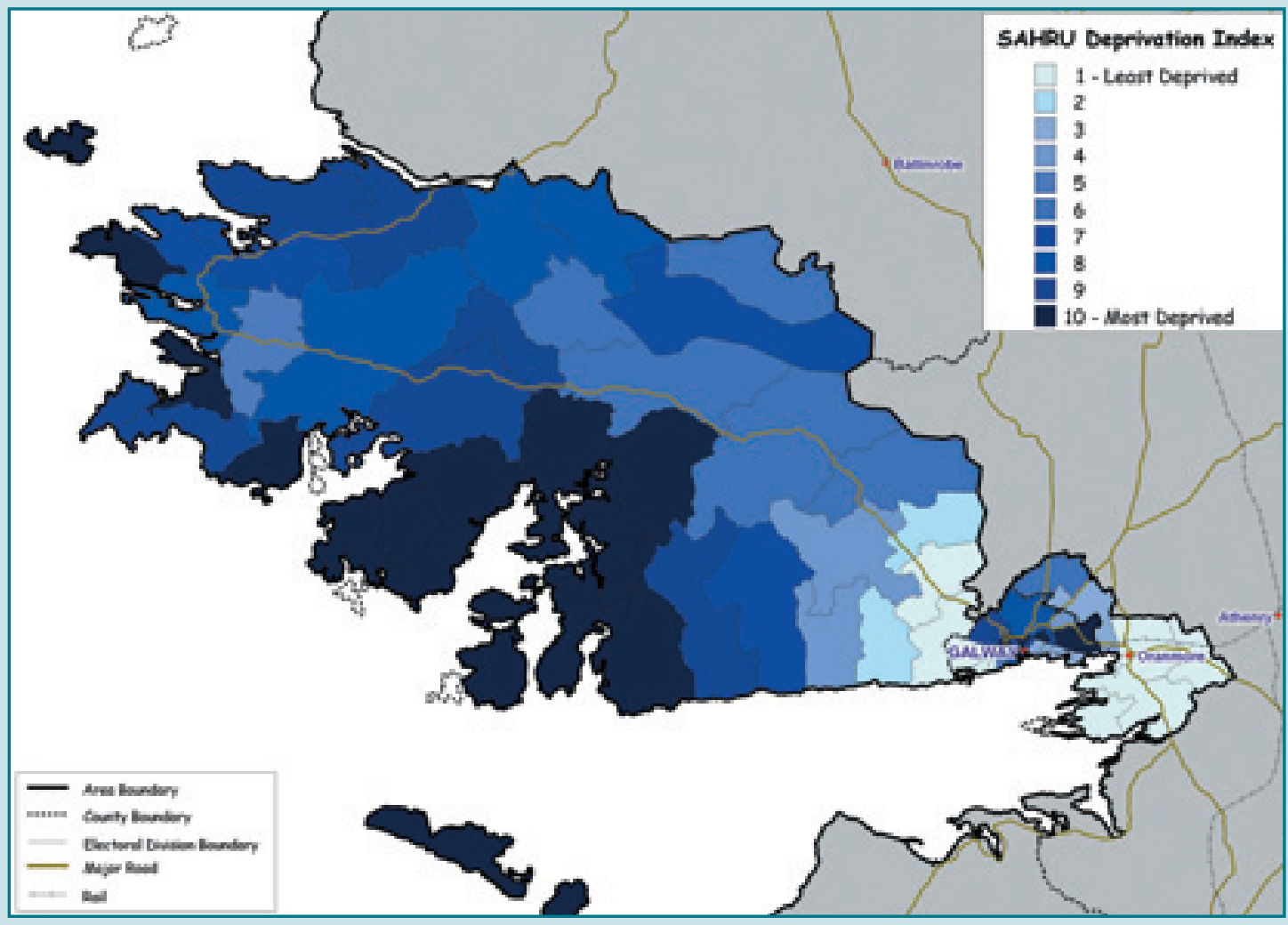


Persons living in Mayo Mental Health Catchment Area by level deprivation

\begin{tabular}{|r|r|r|r|}
\hline $\begin{array}{l}\text { SAHRU } \\
\begin{array}{l}\text { Deprivation } \\
\text { Index (2002) }\end{array}\end{array}$ & $\begin{array}{l}\text { No. of Electoral } \\
\text { Divisions }\end{array}$ & $\begin{array}{l}\text { Catchment Area } \\
\text { Population }\end{array}$ & $\begin{array}{l}\text { \% Catchment } \\
\text { Area Population }\end{array}$ \\
\hline 1 & 0 & 0 & $0.00 \%$ \\
\hline 2 & 7 & 6,873 & $5.85 \%$ \\
\hline 3 & 15 & 15,653 & $13.33 \%$ \\
\hline 4 & 8 & 5,326 & $4.53 \%$ \\
\hline 5 & 18 & 13,331 & $11.35 \%$ \\
\hline 6 & 15 & 7,929 & $6.75 \%$ \\
\hline 7 & 25 & 15,946 & $13.58 \%$ \\
\hline 8 & 20 & 24,316 & $20.70 \%$ \\
\hline 9 & 22 & 14,049 & $11.96 \%$ \\
\hline 10 & 22 & 14,023 & $11.94 \%$ \\
\hline Total & 152 & 117,446 & \\
\hline
\end{tabular}

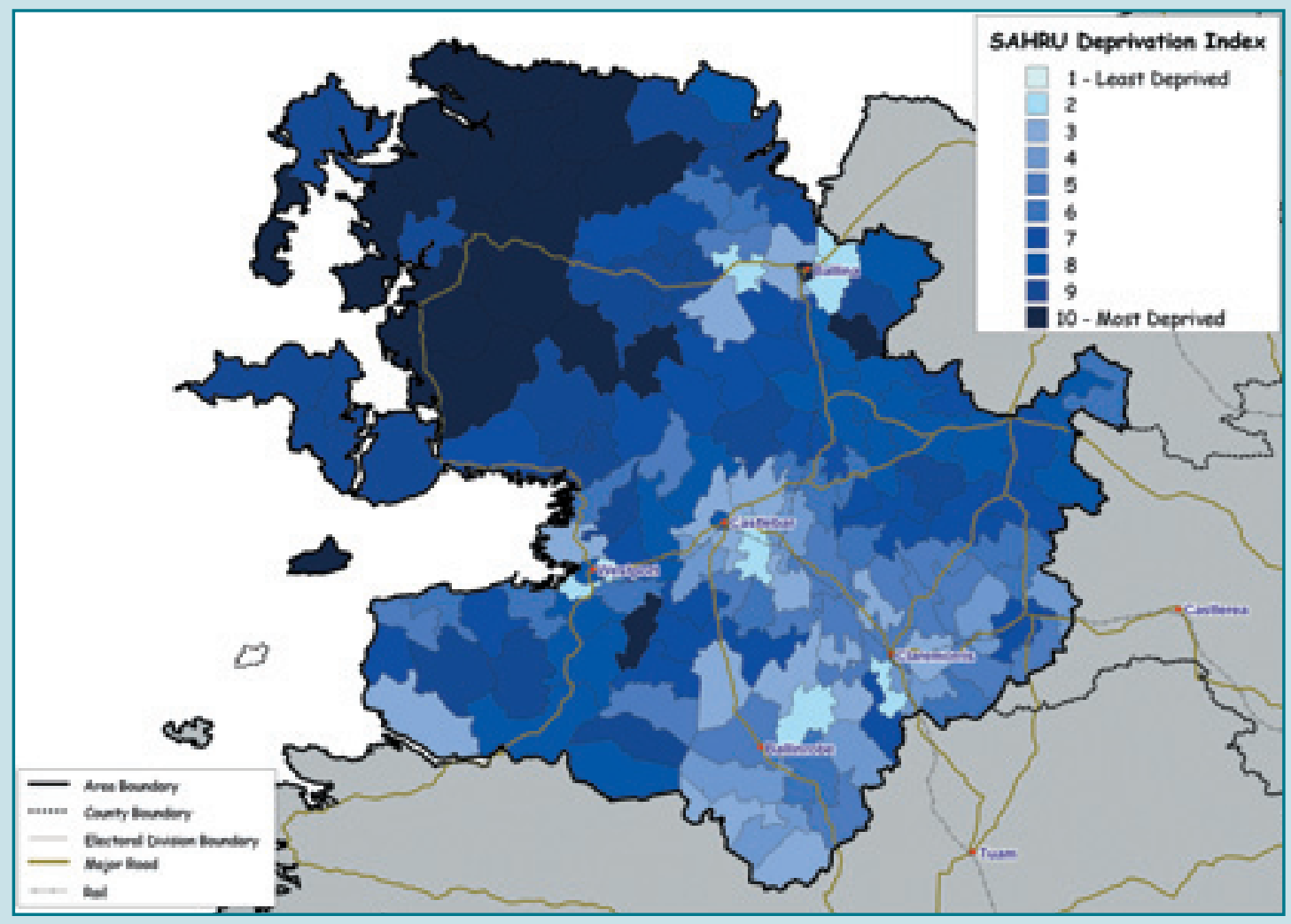


Persons living in Roscommon Mental Health Catchment Area by level of deprivation

\begin{tabular}{|r|r|r|r|}
\hline \begin{tabular}{l} 
SAHRU $\begin{array}{l}\text { Deprivation } \\
\text { Index (2002) }\end{array}$ \\
\hline 1
\end{tabular} & $\begin{array}{l}\text { No. of Electoral } \\
\text { Divisions }\end{array}$ & $\begin{array}{l}\text { Catchment Area } \\
\text { Population }\end{array}$ & $\begin{array}{l}\text { \% Catchment } \\
\text { Area Population }\end{array}$ \\
\hline 2 & 14 & 7,615 & $14.10 \%$ \\
\hline 3 & 11 & 7,106 & $13.16 \%$ \\
\hline 4 & 15 & 6,338 & $11.74 \%$ \\
\hline 5 & 15 & 4,909 & $9.09 \%$ \\
\hline 6 & 15 & 5,287 & $9.79 \%$ \\
\hline 7 & 10 & 5,761 & $10.67 \%$ \\
\hline 8 & 14 & 5,734 & $10.62 \%$ \\
\hline 9 & 14 & 8,683 & $16.08 \%$ \\
\hline 10 & 4 & 931 & $1.72 \%$ \\
\hline Total & 1 & 1,643 & $3.04 \%$ \\
\hline
\end{tabular}

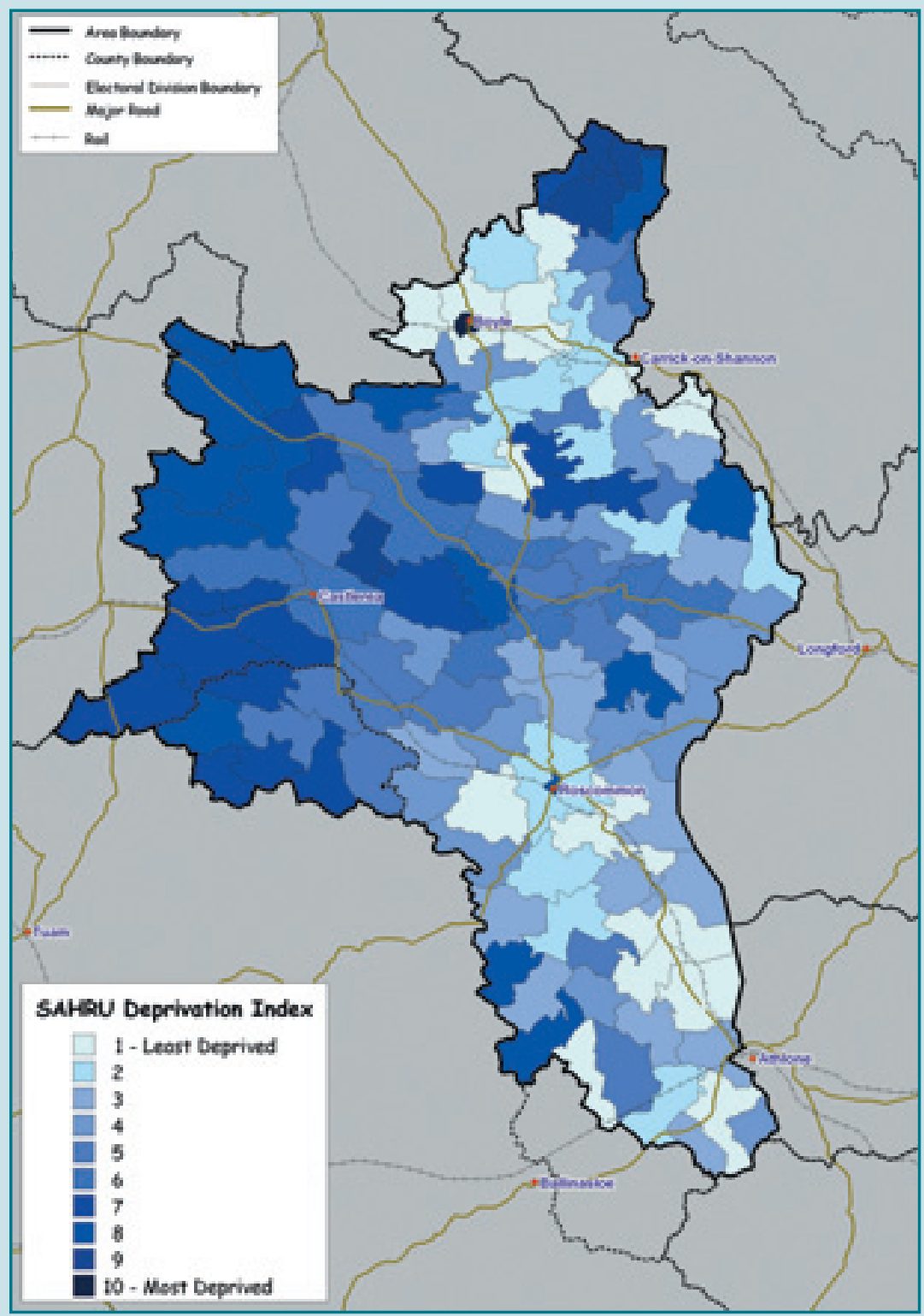




\section{References}

Barron, S. and Mulvany, F. (2005) National Intellectual Disability Database Committee Annual Report 2005. Dublin: Health Research Board

Daly, A., Moran, R., Walsh, D. \& Kartalova O'Doherty, Y. (2004) Activities of Irish Psychiatric Services 2003. Dublin: Health Research Board

Department of Health (1984) Planning for the Future. Dublin: Stationery Office.

Hickey, T, Moran, R. and Walsh, D. (2003) Psychiatric Day Care - An Underused Option? Dublin: Health Research Board

Kelly, A. Teljeur C. (2004) A New National Deprivation Index for Health and Health Services Research. Short Report. Small Area Health Research Unit, Department of Public Health \& Primary Care, Trinity College Dublin

Mental Health Commission (2005) Annual report of the Mental Health Commission 2004, Including the Report of the Inspector of Mental Health Services. Dublin: Mental Health Commission 
Activity and catchment area characteristics 2004 